Balls on Walls

\title{
Balls on Walls, Feet on Streets: Subversive Play in Grand Ducal Florence
}

On the 17th of February 1529 youths put on a match of calcio in livrea, not only to continue the old custom of playing calcio for carnival, but even more to show public contempt for their enemies... and in order not only to be heard, but also seen by their enemies they put a party of musicians with trumpets and other instruments in the chimney of the roof of Santa Croce, whereupon from Giramonte there was fired a cannon at them:

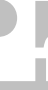
but the ball went high, and it did not do damage to anyone. ${ }^{* 1}$

\section{-Benedetto Varchi, Storia fiorentina, Book XI}

From 24 October 1529 to 10 August 1530, an Imperial army fighting for Charles V and Pope Clement VII besieged Florence. In the years before the siege, the city had ousted the ruling Medici family and was enjoying a brief resurgence of republicanism. Now with enemy armies at the gates waiting to reinstate the Medici government, the Florentines resisted the attack by waiting inside their city walls, and famously, by playing calcio, their city's popular ball game.

As Benedetto Varchi would later recount in his Storia fiorentina, on 17 February young men gathered in Piazza Santa Croce and played the ball game in resistance of the siege. Wanting to be both seen and heard by their enemies, the young men projected music from the roof of the church in order to boldly broadcast their contempt for the attack, even under the threat of cannon fire. During this republican era, calcio was a competition between the four quarters of the city, a local

\footnotetext{
* I am thankful for suggestions and contributions to this article from Niall Atkinson, Irene Backus, Sean Roberts, Chris Zappella, and Rebecca Zorach. This research also benefitted from comments at the 'Comparative Perspectives on Early Modern Street Life' panel at the Renaissance Society of America conference in Berlin, 2015, as well as the 'Spatial Histories of the Early Modern Italian City' panel at the College Art Association conference in New York, 2015.

${ }^{1}$ Benedetto Varchi's Storia Fiorentina was first published in 1721. See Benedetto Varchi, Storia Fiorentina di Messer Benedetto Varchi, Libro XI (Colonia: Pietro Martello, 1721): 346, 'Agli diciassette i giovani, sì per non intermettere l'antica usanza di giuocare ogn'anno al Calcio per Carnovale, e sì ancora per maggior vilipendio de'nemici, fecero in sulla piazza di santa Croce una partita a livrea, venticinque bianchi e venticinque verdi, giuocando una vitella, e per essere non solamente sentiti, ma veduti, misero una parte de' sonatori con trombe e altri strumenti in sul comignolo del tetto di santa Croce, dove dal Giramonte su lor tratto una cannonata, ma la palla andò alta, e non fece male nè danno nessuno a persona.' For analysis of the Storia in preparation of a new critical edition, see Dario Brancato and Salvatore Lo Re, 'Per una nuova edizione della Storia del Varchi: il problema storico e testuale,' Annali della Scuola Normale Superiore di Pisa Classe di Lettere e Filosofia, Serie 5, 2015, 7/1, 201-231.
}

This is the author manuscript accepted for publication and has undergone full peer review but has not been through the copyediting, typesetting, pagination and proofreading process, which may lead to differences between this version and the Version record. Please cite this article as doi:10.1111/ rest.12314. 
Balls on Walls

game synonymous with valorous combat and associated with neighbourhood and civic pride, making it an ideal choice for symbolically defying the reinstatement of the tyrannical Medici government. The youths' use of calcio in a moment of war speaks to the potential seriousness of games. Play in the piazza was an activity to be seen and heard, an activity capable of carrying a political message.

When the siege of Florence ended and the Medici returned to power, the reinstated government worked to re-write the history of the republican era, in part by controlling urban space and repurposing popular games and festivals to glorify themselves and support their dynastic interests. The Grand Duchy even repurposed the calcio game, hosting matches for weddings and family events and using the calcio as a diplomatic gift by presenting a match to Henri III of France in Lyon in 1575. According to one account, Henri was so impressed by the game and the sight of the two squads, the one costumed in yellow satin trimmed with silver, and the other in white satin trimmed with gold that he queried, 'Are all the Florentines so beautiful and grand as these? ${ }^{2}$ Only the nobility was permitted to participate directly in these calcio in livrea games, with the perfected forms of their silk and satin clad bodies representing the beauty and greatness of the city itself. Raffaello Gualterotti's (1544-1638) painting of the $A$ Game of Calcio (1589) (Fig. 1) depicts the players in the field positioned in elegant poses. It emphasises the figure of their bodies adorned in gold-trimmed, pink and blue uniforms over the action of the game. Festal culture functioned as an instrument in a carefully controlled cultural policy; sponsoring festivals and promoting state-controlled versions of games like calcio was a way to

\footnotetext{
${ }^{2}$ In Pietro di Lorenzo Bini, Memorie del calcio fiorentino tratte da diverse scritture (Stamperia di S.A.S. alla Condotta: 1688), 89 .
} 
Balls on Walls

exert authority over bodies, performance, and use of space in the city. ${ }^{3}$ Despite this, the broader transgressive and violent potential of the ludic as enacted in public urban space through youth play continued to be a source of anxiety for the Grand Duchy. ${ }^{4}$ While the Medici indeed appropriated calcio for their own interests, ball games remained popular quotidian activities, with young men similar to those described by Varchi continuing to play calcio in the streets and piazzas of Florence.

This article focuses on these balls games and acts of play in urban space. It draws attention to the social and political import of the everyday games played on the streets of Florence from the fall of the republic in 1530 through the rule of Cosimo I and the rise of the Grand Duchy under Ferdinando I. At the same time that the Medici were commissioning artworks that rhetorically promoted a unified identity of Florence and a spectre of control over the city space through the apparatus of public games like calcio in livrea, the populace engaged in transitory activities of play in the street that contributed to community identity and belonging in space. These activities have been often overlooked in a history of urban space due both to a dearth of evidence and to notions that such play does not seriously relate to the public life of the city, nor merits academic study. ${ }^{5}$ My research responds to calls for more substantive work on how everyday movement and memory relate to community building in urban space by

\footnotetext{
${ }^{3}$ For a reading of games and festivals in support of the Medici dynasty, see: Horst Bredekamp, Florentiner Fussball: Die Renaissance de Spiele (Berlin: Verlag Klaus Wagenbach, 2006) and Michel Plaisance and Nicole Carew-Reid, Florence in the time of the Medici: public celebrations, politics, and literature in the fifteenth and sixteenth centuries (Toronto: Centre for Reformation and Renaissance Studies, 2008).

${ }^{4}$ For popular violence and youth organization, see Robert Davis, The war of the fists: popular culture and public violence in late Renaissance Venice (New York: Oxford University Press, 1994) and Natalie Zemon Davis, 'The Reasons of Misrule: Youth Groups and Charivaris in Sixteenth-Century France,' Past \& Present 50 (Feb., 1971), 41-75.

${ }^{5}$ Gherardo Ortalli, Professor at Università Ca Foscari Venezia, notes this problem for game studies in his discussion of the creation of the Fondazione Benetton, the leading institution in Italy dedicated to the history of games. Ortalli summarizes the age old argument against academic study of games: game play has been considered structurally different than subjects of serious study, and thus, since games have not been thought to be not serious, they do not merit serious scholarship. See Gherardo Ortalli, 'Alla scoperta della serietà del gioco,' Fondazione Benetton Studi Ricerche: http://en.fbsr.it/fbsr.php/History_of_Games/History_of_games_and_gaming (accessed 10/9/2016)
} 
Balls on Walls

introducing new evidence that sheds light on everyday play, including play by the less than aristocratic classes. ${ }^{6}$ A sixteenth-century manuscript found in the Biblioteca Laurenziana supplies a wealth of information about street play by listing and describing nearly one hundred games enacted by youths in urban space. In considering the kind of play described in the Laurenziana manuscript alongside letters from the Medici archive that recount youth play and artworks depicting public festivals commissioned by the Medici, we can see how games forged competing and fluid topographies in the urban environment through the interpenetration of the quotidian, ludic, and festal. Teasing out the transgressive and political potential of the ludic apart from and apart of the festal demonstrates how games in the city produced moments of community in an early modern public sphere- a sphere carved out through use of and performance in urban space, a sphere sometimes contending with and in contention with legislation, control, and authority by the Grand Duchy. ${ }^{7}$

In concert with recent studies of the Medici Grand Duchy that rethink the narrative of its absolute power and studies of sports' contribution to collective identity, the Medici's appropriation of popular games, commission of artworks presenting those games as dynastic symbols, policing of class in relation of games, and attempts to control play on the street all

\footnotetext{
${ }^{6}$ See Fabrizio Nevola and David Rosenthal, Urban Communities in Early Modern Europe (1400-1700): A Research Review, 2011. Urban space and community have recently been widely considered in a broader European context, in particular by the Making Publics project at McGill University. For a much needed look at the physical spaces, locations, institutions, and materials involved in public making, see: Angela Vanhaelen and Joseph P. Ward, Making Space Public in Early Modern Europe: Geography, Performance, Privacy (London: Routledge, 2013). For a new look at the role of language, literature, and the exchange of ideas in creating publics, see: Paul Yachnin and Marlene Eberhart, Forms of Association: Making Publics in Early Modern Europe (Amherst: University of Massachusetts Press, 2015)

${ }^{7}$ Traditional views of an early modern public have been based in the writings of Habermas, see Jürgen Habermas, Strukturwandel der Öffentlichkeit. Untersuchungen zu einer Kategorie der bürgerlichen Gesellschaft (Frankfurt am Main: Suhrkamp, 2010). Recent scholarship has sought to complicate his work, focusing on the multiplicity of experiences, networks, performances, and voices. See Massimo Rospocher, Beyond the Public Sphere: Opinions, Publics, Spaces in Early Modern Europe (Bologna: Berlin: Il Mulino; Duncker \& Humblot, 2012). On the rhetoric and representation of space and the intellectual history in the early modern public, see Bronwen Wilson and Paul Yachnin, eds. Making Publics in Early Modern Europe: People, Things, Forms of Knowledge (New York: Routledge, 2010)
} 
Balls on Walls

speak to the substantiveness of the ludic. ${ }^{8}$ Play shaped the production, use, and meaning of the urban environment both in daily life and during special events. In turn, the city's socially invested topography contributed to the construction of Florentine identity, within, between, and beyond factions.

\section{Calcio: 'Justly our own Florentine game'}

In the weeks preceding the marriage of Lucrezia de' Medici to Alfonso II d'Este (3 July 1558), Florence held lavish celebrations and games, including a match of the calcio in livrea in Piazza Santa Maria Novella. ${ }^{9}$ A few years later, Giovanni Stradano likely represented the event in his series of paintings of public festivities in the Sala di Gualdrada in the Palazzo Vecchio (Fig. 2). ${ }^{10}$ Both the subject matter of the image of calcio in Piazza Santa Maria Novella and how Stradano has rendered the scene in the Sala Gualdrada speak to the calcio's activation of space, propagation of identity, and the Medici's assertion of authority. In Stradano's image, spectators create a rectangular playing field the uniformity of which is echoed by the receding lines of the surrounding buildings. In the center, two squads dressed in red and yellow play the rugby-like ball game. The linear perspective of this image emphasises the regularity of the piazza, creating a controlled space for the chaos and violence of the game. The space of the Piazza Santa Maria

\footnotetext{
${ }^{8}$ See Domenico Zanrè, Cultural Non-Conformity in Early Modern Florence (Burlington, VT: Ashgate, 2005) and 'Athletics within the social fabric,' in John McClelland, Body and Mind: Sport in Europe from the Roman Empire to the Renaissance (London: Routledge, 2006), 114-131.

${ }^{9}$ Giuseppe Corazzini, Diario fiorentino di Agostino Lapini (Florence: Sansoni Editore, 1900), 121: 'A' di 2 di luglio 1558 si fe' al Calcio a S. M. Novella, a ore $22 \frac{1}{2}$ che furono 30 per parte'

${ }^{10}$ E. Allegri and A. Cecchi, Palazzo Vecchio e i Medici (Florence: Guida storica, 1980): 211. Heidi Chrétien interprets Stradano's work in the Sala Gualdrada in the context of the Festival of San Giovanni, often usefully, though she strains to fit each scene within this context, and thus I see these images as better interpreted in the context play in urban space in Florence more broadly, see Heidi L. Chrétien, The Festival of San Giovanni: Imagery and Political Power in Renaissance Florence (New York: Peter Lang Pub Incorporated, 1994); for an interpretation of Stradano's work in the Sala Gualdrada as a political tool for Cosimo I, see: Henk Th. van Veen, Cosimo I de' Medici and his Self-Representation in Florentine Art and Culture (Cambridge: Cambridge University Press, 2006), 42.
} 
Balls on Walls

Novella, however, is not as regular as Stradano makes it appear. Stefano Bonsignori's 1584 map of Florence represents the piazza from above, illustrating its irregular trapezoidal space, which is still clearly visible today (Fig. 3-4). ${ }^{11}$ Stradano, who knew the calcio game intimately, uses perspective and his composition to highlight how the rectangular playing field of the calcio game brings spatial order to the piazza. ${ }^{12}$ Stradano also makes a statement with the very placement of the game in the Piazza Santa Maria Novella: Earlier republican calcio games typically occurred in the Piazza Santa Croce, not the Piazza Santa Maria Novella. It is this conspicuous change of locale that suggests the match represented is the celebration of Lucrezia and Alfonso II's wedding, a match which, as recounted by the Florentine diarist of Agostino Lapini, emphasized the lavishness of the spectacle and the adorned bodies of the noble 'signorile' participants dressed in gold and silver to honor Florence, rather than the most skilled. ${ }^{13}$

Stradano's image speaks to a rhetoric of control over urban space and the use of calcio to promote a specifically Florentine identity. Florentine poets lauded the virtues of calcio, the city's emblematic game, and attributed to it a noble lineage tracing back to ancient Greece and Rome.

In the third edition of the Accademia della Crusca's dictionary, calcio is listed as, 'a game, proper and ancient of the city of Florence, in the manner of an ordered battle, with a ball, similar to Sferomachia, passed from the Greeks to the Romans, and from the Romans to us. Lat.

\footnotetext{
${ }^{11}$ Bonsignori's map has been digitized by the Decima Project, a resource to which this project is indebted, see: http://decima-map.net/. See also: Nicolas Terpstra and Colin Rose, Mapping Space, Sense, and Movement in Florence: Historical GIS and the Early Modern City (New York, NY: Routledge Research in Digital Humanities, 2016)

${ }^{12}$ Stradano depicts calcio several times, and records show he was supposed to do a series of frescos on calcio at the Villa in Poggio a Caiano. See Dorine van Sasse van Ysselt, 'Il Calcio Fiorentino disegnato da Giovanni Stradano,' Mitteilungen des Kunsthistorischen Institutes in Florenz, 37. Bd., H. 2/3 (1993): 481-487.

${ }^{13}$ Giuseppe Corazzini, Diario fiorentino di Agostino Lapini (Florence: Sansoni Editore, 1900), 121: 'vestiti tutti, cioe 30, di teletta d'oro in campo rosso, e 30 di teletta d'argento, che fu cosa signorile. Furono vincenti la teletta d'argento; e chiamossi il 'Calcio de' Vagliati,' cioe furno quelli che non furono accettati' For the calcio players' bodies in the piazza in relation to festal culture, see: Allie Terry-Fritsch, Somaesthetics and the Renaissance: Viewing Bodies at Work in Fifteenth-Century Italy (forthcoming)
} 
Balls on Walls

Harpastum, harpasti ludus. ${ }^{14}$ What's more, the calcio was played on the Feast Day of

Florence's patron saint, Saint John the Baptist. Calcio served to unify the city, bringing people together in the piazza, under the banner of their Florentine-ness as perpetuated by Medici control. Giovanni de' Bardi wrote a treatise on calcio, Discorso sopra il giuoco del calcio fiorentino (1580), and dedicated it 'Al Sereniss. Gran Duca di Toscana.' De' Bardi's work not only praises the virtues of the calcio game, but also describes the rules of the game and the order of the pageantries in detail. Similar to Stradano's image of the calcio, the perspective in the etching accompanying Bardi's work also creates a sense of stability in the composition of the image, emphasizing the orderliness of the playing field (Fig. 5). After describing the games of the ancients, in his introduction Bardi calls calcio, 'justly our own Florentine game,' a game to showcase the nobility and excellence of Florence, in the same manner as did the games of ancient Rome. ${ }^{15}$ And yet, despite that in many ways calcio was emblematic of the unity of the city and the control of the Medici rulers, images of calcio show the possibility and potential for discord and disunity surrounding the game. The orderliness of Bardi's image belies the violent and chaotic nature of the game, both on the part of the players and spectators, and throughout the image there are hints at the tumultuous nature of the game. Fires lit atop the roofs surrounding the piazza billow into an ominous cloud of black smoke above the scene. Armed guards patrol the field from inside the fences, perhaps keeping the crowds of spectators out and creating an uneasy sense that the violence of calcio is not something controlled within the playing field, but rather that the tumult pervades the space of the piazza. Both de' Bardi and Stradano's images of

\footnotetext{
${ }^{14}$ Accademia della Crusca, Del Vocaobolo della Crusca nella Terza edizione stampato in Firenze, alla voce (Florence: Stamperia Giunta, 1612), 107: 'è Calcio anche Nome d'un giuoco, proprio, e antico della Città di Firenze, a guisa di battaglia ordinato, con una palla a vento, rassomigliantesi alla sferomachia, passato da' Greci a' Latini, e da Latini a noi. Lat. Harpastum'

${ }^{15}$ Giovanni de' Bardi conte di Vernio, Discorso sopra il giuoco del calcio fiorentino del Puro Accademico Alterato (Florence: Giunti, 1580), 4: 'proprio nostro giuocho Fiorentino'
} 
Balls on Walls

calcio demonstrate not only the desire to organize space and control people through the apparatus of the game, but also and conversely the very need for control, the potential for violence and chaos, and the game's reach beyond the playing field.

\section{Play on the Street}

While the Medici incorporated games like calcio into their state-sponsored festivities with an aim to control and manage urban space and the populace, on a quotidian basis young men also laid claim to the streets by playing games. ${ }^{16}$ Richard Trexler posited the political social impact of these giovani, or young men, noting that in the fifteenth century they were participating in ball games called calcio. A poem from 1460 by Giovanni Frescobaldi describes a game, palla di Calcio, in Piazza Santo Spirito, 'And there were fifteen of this quarter of Santo Spirito, of equal skill, Strong as bulls and light of foot, Who want to make their fame prevail. On the other team were as many squires, Hoping to attain honor; They are called Players of the Meadow, And are so disciplined at Calcio. ${ }^{17}$ The poem alludes to the game as an engine for public building in several ways. On the one hand, the young men are grouped both by the physical space of Piazza Santo Spirito as the place of the game and the sense of a neighbourhood identity, their quartiere. On the other hand, the poem imagines the players as squires pledged as 'Players of the Meadow,' a mock chivalric clan engaged in the ball game as battle. Calcio created identity and community both in reality and representation, not only during the time of the

\footnotetext{
${ }^{16}$ For an early comprehensive overview of public games in early modern Italy, see: William Heywood, Palio and Ponte (London: Methuen, 1904) and for a font of primary sources on public games, see: 'Festivities and Popular Pastimes,' Chapter 6: Artisans and Workers in R. Burr Litchfield, Florence ducal capital, 1530-1630 (New York: ACLS Humanities E-Book, 2008).

${ }^{17}$ Richard C. Trexler, Public Life in Renaissance Florence (New York: Academic Press, 1980), 398. See also Antonio Lanza, Lirici Toscani del Quattrocento (Rome: Bulzoni, 1975), 601-607.
} 
Balls on Walls

game, but also beyond by reinforcing the sense of the quartiere and by activating and controlling the space of the piazza.

Although less evidence about these ephemeral and episodic moments of play survives in comparison to the Medici's grand, state-sponsored games, a manuscript in the Biblioteca Laurenziana from the turn of the sixteenth century lists and describes nearly one hundred popular games, including calcio, in which young men transformed walls and streets into ball courts and places of play. ${ }^{18}$ The games to be described are divided into general categories such as on the ground, on the wall, on the table, on horse, in the air. Within these specific types of games are noted, including jousting, either by horse or on foot, games with clubs, games played with tables, games with whips, jumps in the air, acrobatics, and feats of strength. ${ }^{19}$ The writer states that 'they will describe many kinds of games that will serve youths according to their places,' 'i luoghi. ${ }^{20}$ The surrounding urban space was important for the play of these games. For example, within the general type of game the author describes as 'al Muro,' or 'at a wall,' there were many types of games played at the wall, including jumping over walls with the aid of a stick, sitting atop walls, slapping walls, or one game, 'To jump at the wall with a stick,' wherein running alongside the wall, the youth stabs his stick into the wall, and then holding tight jumps over the

\footnotetext{
${ }^{18}$ Biblioteca Laurenziana, Manoscritto: Ashb. 732, ca. 1500. The manuscript is first analyzed and sections transcribed by Albertina Furno, 'Un codice di giuochi popolari fiorentini del secono XVI,' in Rivista delle biblioteche e degli archivi periodico di biblioteconomia e di bibliografia di paleografia e di archivistica, dir. Giudo Biagi. Florence-Rome, 1903. Vol. XIV, N. 7-8 Anno. XIV, 54-57, 97-110. The manuscript has recently been considered by John McClelland, Body and Mind: Sport in Europe from the Roman Empire to the Renaissance (London: Routledge, 2006).

${ }^{19}$ Biblioteca Laurenziana, Manoscritto: Ashb. 732, ca. 1500, fol. 13v 'Vogliamo descrivere qualche parte di piu sorte giouchi quali sono questi (in margin noted as 'Generali') Interra Al muro Alla tavola Al cavallo In aria (in margin noted as 'Particolari') "Alla schoreggia A saltare al muro A saltare interra A saltare in aria A fare tomboli A trarre per forza di braccia A scharicha Parigi Alle lotte franzese Et di piu sorte giuochi’

${ }^{20}$ Biblioteca Laurenziana, Manoscritto: Ashb. 732, ca. 1500, fol. 13v: 'Noi da indi in nanzi descriverreno molte sorti di giuochi, accio, la moltitudine di giovani se ne possino servire secondo i luoghi et pigliare quelli che alloro parranno...'
} 
stick and returns to the ground safely. ${ }^{21}$ Other games demonstrate mischief involved in these games, such as the game of 'To spin with a stick and put out the light,' in which the player must dizzy himself by putting the stick on his shoulders and turning on the ground and then put out a candle with the end of a stick. The author notes the game is difficult and most fall, and it is good for the player to keep his eyes closed, so one can imagine the possible destruction and associated with this kind of chaotic play with fire and sticks. ${ }^{22}$

The Medici government took note of this kind of quotidian play and youth games, and was interested in controlling such play in the streets and piazzas of Florence. In a letter to Cosimo I on 12 April 1549, his secretary informs the duke that some youths have been playing a ball game called pall-mall, a precursor of cricket:

...it lasted for some months, gatherings of young people passing time playing pall-mall in the communal street, dining sometimes.... The same gathering of every kind of youths...They are noble youths without work, and they need something to do, and to me it is enough that Your Excellence knows about it, for my sake. ${ }^{23}$

Although Cosimo's secretary seems to downplay the importance of this months-long takeover of

Via Faenza to play ball, he also thinks it significant enough to describe to the Duke. He changes his tune, however, first describing the youths as of every kind and then later insisting on their nobility -- youths without any work to do. In this, the secretary implies it is less worrisome if noble youths take-over of the street than if the artisan class were to do so. In another letter,

\footnotetext{
${ }^{21}$ Biblioteca Laurenziana, Manoscritto: Ashb. 732, ca. 1500, fol. 23r: 'Anchora pigliando uno chamato, et piglinndo corsa corri al muro et appoggia la punta di detto camato al muro, tenendolo forte et co' ambi li tua piedi salta di sopra adetto camato tornando'

22 Biblioteca Laurenziana, Manoscritto: Ashb. 732, ca. 1500, fol. 16r: 'A girare col bastone et spegnare il lume'

${ }^{23}$ Archivio di Stato di Firenze (henceforth ASF), Mediceo del Principato, Vol. 613, fol. 22. 'et vi si durò per alquanti mesi a fare adunata di giovani passando tempo col pall'a mmaglio per la strada comune, cenandovi alcuna volta. De poi cessò quella voga. Hora da poi che V. Ex. è partita di qua hanno cominciato a farvi la medesima radunata d'ogni sorte di giovani, giocando a detto pall'a maglio per la strada et cenandovi alcuna volta come facevano l'altra. Sono giovani nobili et senza exercitio, et bisogna faccino qualcosa, et a me basta che V. E. il sappia per il debito mio.'
} 
Balls on Walls

Cosimo is informed that, '[m]any youths from the San Giovanni quarter of the city these nights have played a game of pome in Piazza San Marco with bonfires and trumpets. ${ }^{\text {,2 }}$ The subject of Stradano's image of a Game with Bonfires in Piazza Santo Spirito has thus far remained unidentified, but I posit it depicts just such a game of pome (Fig. 6). The Laurenziana manuscript also explains the game of pome in detail, a wrestling game in the style of prisoner capture requiring fewer players than calcio, 14 total from which 2 squads elect leaders and defend against capture and attempt to capture players from the other team, played in a large field much like calcio. ${ }^{25}$ A song called, 'The Song of the Game of Pome' by Il Lasca in the Canti Carnascialeschi notes that while once played nude in pastoral settings, as the Laurenziana manuscript describes, pome is now played clothed, in urban contexts as the letter to Cosimo I indicates. ${ }^{26}$ Although set in Piazza Santo Spirito rather than Piazza San Marco, Stradano's image similarly shows a wrestling game with trumpets playing and bonfires lit as youths compete in the center of the piazza. The secretary's letter to Cosimo continues, '[a]nd today they came to me

\footnotetext{
${ }^{24}$ ASF, Mediceo del Principato, Vol. 613, fol. 17. 1549 May 20: 'Molti giovini del quartier di San Giovanni a queste sere hanno facto al pome su la piazza di San Marco con fuochi di stipa et suoni di trombe'

${ }^{25}$ Biblioteca Laurenziana, Manoscritto: Ashb. 732, ca. 1500, fol. 20r: 'Al pome. Il giuocho del pome è più libero, et più sciolto et mancho terminato, et di minor numero di giovani, ch' il Calcio, et ne nostri tempi mancho honesto, perche nudo si gioucho, et per questo e piu familiare a pastari, et alle ville che a quelli delle citta. Si fa tal giuocho da 14 giovani de qual dua eletti s'adomandanocomandatori. L ufizio de qual è comandare a suoi, che presti si difendino ond esser presi et presi vadino a pigliari il nimico, il quale preso da vinto una caccia. Sono adunque 6 per banda eletti per sorte da i comandatori in uno spazio di campo prato o renaio di 140 passi o in circa luogho terminato sopra e dis totto dale Bombe quadre, et larghe tanto, nelle quali a fila stieno despossi i giuochatori nudi presso luno all'altro, havendo per uno uno braccio a spazio, nel mezo della lungheza, et largheza e uno termine, Il quale si chiama mezzo pome al quale viene uno davena della Bande a chiedere mezzo pome mandato dal suo coman datore, et alri' contro di questo ne e mandato uno altro, dall'altra parte dal suo comandatore nel medesimo modo per pigliarlo, ma non puo essere preso da lui, ma si bene nel fuggire et trattenerlo debbe ingegnarsi di farlo pigliare da quello de suoi, che inmediate gle mandato aridosso nel pigliarlo et cosi sequita insino che sieno nelle Bombe giucatori.'

${ }^{26}$ Anton Francesco Grazzini, Tutti i trionfi, carri, mascherate o canti carnascialeschi andati per Firenze dal tempo del Magnifico Lorenzo de' Medici fino all' anno 1559 : in questa seconda edizione corretti, con diversi MSS. collazionati, delle loro varie lezioni arricchiti, notabilmente accresciuti, e co' ritratti di ciascun poeta adornate (Lucca, 1750), 501: 'Ingnudi esser convien di mano in mano, Ma pur si trova ancor qualche dappoco, Che l' usa far vestito, e noi '1 sappiamo; Ma s'affatica in vano.' For further discussion of pome, see Chapter 7 of John McClelland, Body and Mind: Sport in Europe from the Roman Empire to the Renaissance (London: Routledge, 2006)
} 
Balls on Walls

and said they would like to with your grace to continue to party in this manner tonight. ${ }^{27}$ On the one hand, the youths have already taken over the piazza -- they organized a game in a mode similar to sanctioned public sports, complete with bonfires and the musical accompaniment of trumpets. On the other hand, the youths ask for Cosimo's permission to continue their merriments, reflecting the fluid topography and spheres of authority over urban space. Cosimo's secretary suggests to the boys that if they are going to fritter away their time playing ball, perhaps it would be better for them to spend time working in their shops. ${ }^{28}$ Here again, the assumption is that youths of the artisan class should be working rather than playing in the piazza. Contrastingly, when noble youths of the Santa Croce quarter ask Cosimo permission to, 'pass time during the holiday to (play games)... such as the game of the rooster and the goose, the game to kill the cat, and if there are enough players to play pome,' Cosimo responds to the noble youths positively: '[Y]our honest and virtuous pastimes always content His Excellency.' 29 Play in the city by the less than noble classes, by the poor and artisans, was a source of anxiety for the Medici during the Counter Reformation, and they passed laws forbidding play in the street. Lorenzo Cantini's Legislazione toscana raccolta e illustrata (1532-1775) notes ordinances stating there should be "no game-playing in the streets or squares . . no games ... whatsoever of . . cards, dice, bats, balls... ${ }^{30}$ Cosimo I banned the ball game pallone from any central streets of the city, an infraction meriting a 10 scudi fine, allowing it only, 'along the wall

${ }^{27}$ ASF, Mediceo del Principato, Vol. 613, fol. 17. 1549 May 20: 'Et hoggi ne sono venuti da me e dettomi che desiderrebbono con bona gratia di Vostra Eccellentia potere seguire di far un poco di festa in questo serà questo.'

${ }^{28}$ Ibid., 'Imperò s'andranno trastullando con dette pome, ché forse anche sarebbe meglio che alcuni di loro si transtullassino alle botteghe.'

${ }^{29}$ ASF, Vol. 613, Insert: 5 fol. 28. 1549 April 25: 'Le giovini di Santa + desiderano con bona gratia di Vostra Eccellenza passar un poco di tempo in questa festa di Santa + col far la chintana, fare ammazzare la gatta, il gallo et l'ocha, et se si troverranno tanti giocare al pome. Quelli che si trovono capi sono Alammano Bandini, Bernardo Jacopi, Battista della Fonte et simili. Nel ragionamento io ho risposto loro che V. Ecc.a si contenterà sempre d'ogni loro honesto et virtuoso passatempo.'

${ }^{30}$ Lorenzo Cantini, Legislazione toscana raccolta e illustrata (1532-1775), 32 vols. (Florence, 1800-1805), 6:311, 23 August 1566; 7:163, 24 December 1569;13:192, 3 June 1585;13:371, 4 November 1589;14:79, 18 July 1594. 
Balls on Walls

of the city and outside in those places and streets where there are not houses. ${ }^{31}$ By the middle of the seventeenth century, there were placards placed all over Florence indicating that ball games and other games were forbidden in streets and squares. Two such plaques were erected on Via Dante Alighieri and Via dei Magazzini, signaling an attempt to control quotidian play in urban space (Fig. 7-8). Concurrently, the Florentine government placed permanent markers for sponsored games in the urban infrastructure. A round, marble plaque on the Palazzo dell'Antella dating to 10 February 1565 demarcates the mid-point of the playing field of the calcio in the Piazza Santa Croce (Fig. 9). Rule 17 of Bardi's treatise on calcio notes that at the third blow of the trumpets, the designated calcio player bounces the ball off of the marble sign to signify the start of the game. ${ }^{32}$ This marker was significant enough that over fifty years later Giovanni da San Giovanni included the marble sign in his design for new frescoes on the facade of the Palazzo. Additionally, Cosimo I had wooden obelisks set up in Piazza Santa Maria Novella to mark the route of his newly-instated chariot race held on the Feast of Saint John, and these wooden obelisks were later replaced by marble ones designed by Bartolomeo Ammannati in 1608 (Fig. 3 and 10). ${ }^{33}$ The obelisks in Piazza Santa Maria Novella and the marble plaque on the Palazzo dell'Antella in concert with the plaques forbidding quotidian ball games demonstrate how festal culture attempted to control the ludic and subvert its transgressive potential by bounding play within the prescribed times and places allowed by the government.

\footnotetext{
${ }^{31}$ See Luciano Artusi and Silvano Gabbrielli, Feste e giochi a Firenze (Florence: Becocci, 1976), 72, 'lungo le mura di detta città e fuora in quelli luoghi e strade dove non siano case sotto pena a chi contraffacessi di scudi dieci d'oro per ciasuna volta o di dua tratti di fune'

32 Bardi, 15: 'Il principio de fieri movimenti del Calcio è batter la palla; il che si usa far nel mezzo del campo da quell lato, che muro si chiama dov'è posto alcuno segno, o di marmo, o d'altro il quale il mezzo a punto dimostri questo battere è uffizio del pallaio, il quale vestito d'ambedue i colori della Livrea, come huomo di mezzo giustamente la palla batter il detto marmo si diritto"

${ }_{33}$ Florence, ASF Manoscitti Settimanni, Diario di Francesco Settimanni. See also Pietro Gori, Feste Fiorentine Attraverso i secoli (Florence: Giunti, 1989), 232 and John McClelland, Body and Mind: Sport in Europe from the Roman Empire to the Renaissance (London: Routledge, 2006), 109.
} 
Balls on Walls

Sanctioned public festivities were seen as important tools in managing the public, a controlled outlet for pent-up violence and oppression amongst the working classes of Florence. Author and satirist Traiano Boccalini (1556-1613) in his De' Ragguagli di Parnaso jeered that the wise Florentine politicians and courtiers allow for the violence of the calcio in order to alleviate social stress through the violence of the game. ${ }^{34}$ Although in his tract Boccalini mocks the politicians, there is still a sentiment of truth to his statement about games as an outlet for the public. In the early and middle sixteenth century, the Medici used public games and carnival season advantageously to mollify the middle and lower classes, even mocking themselves when useful. A masquerade during the 1546 carnival brandished the theme of universal madness, wherein Florentine socialites and political figures were mocked, and social classes were inverted in a spectacular monde renevers. ${ }^{35}$ Initially Cosimo I treated the carnivalesque nature of these games and the temporary surge of lay popular power as bounded- bounded by the rules, identities, and activities played out in the time and space of the game. In response to his secretary Lorenzo Pagni's concerns over certain mocking festivities undertaken by young men in the Accademia del Piano, Cosimo I responded, '[s]ince the minds of the Florentine people do not know how to stay idle, it is better that sometimes they occupy themselves in similar intrigues

\footnotetext{
${ }^{34}$ Traiano Boccalini, De' Ragguagli di Parnaso (1612), Raggualio \#43: 'Ma i politici, gli spiriti de' quali sono più elevati, da quelle risse che molto frequenti nascevano tra i giovani fiorentini, argomentavano che gran misterio s'ascondesse in quel giuoco: percioché le republiche, più delle monarchie — per le continue concorrenze a' magistrati e per le molto frequenti repulse che i senatori hanno da quei carichi che desiderano, gli uni dagli altri senza dubbio alcuno ricevendo più spessi disgusti di quelli che si vede ne' popoli soggetti alla monarchia, — sono piene di odi intestini e di gravi rancori occulti: e che in una libertà, piena d'animi pregni di crudelissimi disgusti, non essendo possibile che non succeda qualche sborramento, dicevano i politici che la republica fiorentina con mirabil prudenza tra i suoi cittadini avea introdotto il giuoco del calcio, solo affine ch'eglino con la soddisfazione di poter da scherzo dar quattro sode pugna a' loro malevoli'

${ }^{35}$ Niccolò Martelli, Dal primo e dal secondo libro delle lettere di Niccolò Martelli, ed. Cartesio Marconcini, (Lanciano: R. Carabba, 1916), 55.
} 
Balls on Walls

rather than remain restless. ${ }^{, 36}$ Cosimo I's political strategy involved not only a network of spies and close knowledge of all the goings on of Florence, but also a tolerance for mockery, dissention, and play when necessary. The temporary inversions of societal norms would be a cathartic outlet for the populace, but would not cause any real changes or problems for the ruling elite. When the joust ended, the parades were over, when carnival turned to Lent, and the temporary benches and fences for calcio were taken out of Piazza Santa Croce, life would return to normal; the streets and piazzas that had been sporting fields would return to being spaces for commerce.

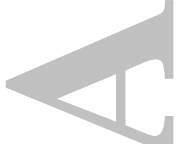

\section{Beyond the Spectacle}

But precisely because the piazzas and streets were not dedicated arenas for play, the ludic extended beyond the central organized festivals, pervading the space of the city and imprinting itself on its structure. More than merely a safety valve releasing social tension, play offered an alternative world, one Bakhtin would later consider in his discussion of the carnivalesque. ${ }^{37}$ Jacques Callot's (1592-1635) etching of calcio for his 1617 series of capricci in Florence for Cosimo II portrays Piazza Santa Croce and gives us a view not only of the calcio match, but also of the edges of the playing-field (Fig. 11). Callot presents a bird's-eye view of the calcio from an invented hill on to the left of Piazza Santa Croce as a drummer dramatically occupies the center of the composition. Callot details action both inside and outside the arena; not only calciatori

\footnotetext{
${ }^{36}$ Domenico Zanre, 'Ritual and Paradoy in Mid-Cinquecento Florence,' in The Cultural Politics of Duke Cosimo I de’ Medici ed. Konrad Eisenbickler, (Aldershot: Ashgate, 2001), 197. ASF, Mediceo del Principato, vol. 623, ff.479r-v.

${ }^{37}$ Mikhail Bakhtin, Rabelais and His World (Bloomington, IN: Indiana University Press, 1984) and Mikhail Bakhtin, 'Carnival and Carnivalesque,' in Cultural Theory and Popular Culture: A Reader, Second Edition ed. John Storey (Harlow: Pearson Education, 1998), 250-260. For the social functions of carnival culture in a broader European context see: David R. Smith (ed.), Parody and Festivity in Early Modern Art, Essays on Comedy as Social Vision (Burlington and Farnham: Ashgate, 2012)
} 
Balls on Walls

chasing after balls and drummers and guards inside the arena, but also the spectators, horses, dogs, carts, and youths running in motion. Another Callot etching of a public game held in Piazza Santa Croce, Battles of the War of Love, Festival of the Grand Duke, presents those at the edges of the playing-field in even more detail (Fig. 12). A raucous crowd surrounds the central spectacle. Spectators watch the game from the roofs. Youths run around. There is fighting and a cart selling hot food - nearly every imaginable kind of accessory to the spectacle. ${ }^{38}$ In one detail Callot imagines two men fighting a mock joust; the figures wear buckets over their heads, foolishly brandishing a toy horse (Fig. 13). Callot's caricatures of the lower classes often portray them in an unfavorable light, which would be consistent with the goals of the print under the patronage of the Medici. Their faces grotesque and masked, their actions comical as the depictions were a source of humor and delight for the aristocratic viewer. Yet, Callot does show the poorer classes of the city alongside the grandiosity of the central festival, thereby making space for the commoners and their activities, something he was perhaps able to do as a foreigner. $^{39}$

Callot's print also shows the kind of youth activities accompanying the official event. In one detail, young men attempt to scale the palchi, temporary stages and bleachers erected for the festival (Fig. 14). The Laurenzina manuscript describes the palcho as the place of the game of the apple, wherein an apple would be strung up from the rafters, and each boy would take turns trying to bite it using only his teeth. Here we see how public festivities themselves created new

\footnotetext{
${ }^{38}$ See: Melissa Calaresu and Danielle van den Heuvel, Food Hawkers: Selling in the Streets from Antiquity to the Present (London: Routledge, 2016)

${ }^{39}$ Jacques Callot was official employed by the Medici Grand Duchy and often portrayed official festivals. He also often created images of the poor. See Dena M. Woodall and Diane Wolfthal, Princes and Paupers: The Art of Jacques Callot (Princeton, N.J.: Yale University Press, 2013). For the role of prints and the public sphere in northern context, see: Angela Vanhaelen, Comic Print and Theatre in Early Modern Amsterdam: Gender, childhood and the city (Burlington, VT: Ashgate, 2003)
} 
Balls on Walls

opportunities for play outside the arena. ${ }^{40}$ A copy of a letter written in 1593 describes this kind of youth play accompanying an official festival, in this case during the ceremonies surrounding Feast of St. John in Piazza del Duomo. ${ }^{41}$ The story begins,

Tuesday morning the $22^{\text {nd }}$ of June, I find myself in Piazza San Giovanni...I will use the club, I reply to them, this not meant to be only held...and I withdrew up the stairs of Santa Maria del Fiore...to save myself I moved to the street of shops, where ... I entered in one of the shops... I planted myself in the shop window above where I arrived, and turned myself toward the wall ... to impede the blows... ${ }^{42}$

This account of play with his friends on the feast day of St. John the Baptist, running through streets and shops wielding bats, points to how official ceremonies and quotidian play intertwined in the streets of Florence. As games like this were repeatedly enacted in the urban infrastructure, they opened the potential for future transgressive play, and even transgressive acts that were outside the realm of play. In another detail of Battles of the War of Love, young men in Callot's print fight with stones; a masked figure leans over aggressively, grasping another figure's neck while that youth raises his arm with a stone in his hand, poised to strike (Fig. 15). Stone fighting was a popular game in Florence, both done in an ad hoc way, such as when bands of youths threw rocks at other bands, or in an officially organized fashion, such as during the 1549 carnival

\footnotetext{
${ }^{40}$ Biblioteca Laurenziana, Manoscritto: Ashb. 732, ca. 1500, fol. 35 v -36 r: 'A pigliare co denti una mela apicchata.'

${ }^{41}$ ASF, Carte strozziane, Series I, 361, fol 101r-v. Copy.

42 Ibid.' 'Martedi mattina, che fumo a 22 di giugnio, Trovandomi in sula piazza di San Giovanni con tanti gentiluomini amici mia, venne il S Jacopo de Medici, et mi chiamo per nome amichevolmi. Et io gli riposi, non posso anevra, perche avevo p.ma à rispondere, à un'altro amico, che mi haveva chiamato, et sbrigttomi da quel gentilhuomo, mi mossi verso lui, che di nuovo mi richiamava, et giuntovi dissi che ci è S. Medici, mi ripose, Mi in dovinano, che voi havesseà trattere in maniera di quel servizio, che se fosse altri, che voi. Io adopererei il bastone, Io gli risposi, questo non è proposito da tenersi nico, et gli detti uno mostraccione, et mi ritirai in su la scale di Santa Maria del Fiore, donde vedendo intricato nel arcciare mano al pugnale, mi mossi per i gli addosso, et egli in questo mentre se lo stringo, et caccio mano al pugniale, il che co me hebbirei sto, mi messi per salvarmi alla volta delle botteghe, dove veggendomelo comparire addosso, entrai in una chi quelle bodeghe chi cio se lo non, piantando mi in salo sportello, dove sui mu arrivo addosso, et tirommi, dove me gli avventar, pigliandolo per se braccia, per impedi i gli il pugniale, et facendo forza di arrovesoiorolo, sull'altra parte detto sportello vicino al muro.'
} 
Balls on Walls

when a stone fight was planned for Via Larga. ${ }^{43}$ This kind of rock throwing, while sanctioned in one context, could spiral out of control in another, with violent and damaging repercussions, such as in 1582 when the stone fight planned on Via Larga to celebrate the wedding of Marriage of Eleanor de' Medici and Duke Vincenzo I Gonzaga caused. The government sought to regulate this kind of game, and Cantini's Legislazione notes an ordinance prohibiting stone throwing in order to protect the new columns in the Mercato Nuovo. ${ }^{44}$

Moreover, while youth play might seem politically insignificant, the similarity of these kinds youth games to the activities of the potenze speak to their potential bearing on later social organization in public space. The potenze were festive brigades who operated during games and public celebrations; they carved up the city into miniature kingdoms, electing leaders who they titled 'emperor' or 'duke' or 'king', organized parades, jousts, and ball games, and forged a strong sense of belonging for their members, a belonging tied to the space of their streets. ${ }^{45}$ The Laurenziana games manuscript describes games that involved the election of a ceremonial leader of the game called the Andrevuolo. The Andrevuolo organized the game, led songs, chose the winners of games, and doled out punishments to the losers. The appointment of the Andrevuolo in youth games evoked the election of the kings, emperors, and dukes that headed the various potenze, modeling the kind of community organization and partisan identity afforded by the lay potenze groups. These youth games primed young men for later participation in the potenze as they laid claim to the public spaces -- from walls, to bridges, to staircases, and piazzas. The Andrevuolo also led the youths in singing songs related to games, such as the song transcribed

\footnotetext{
${ }^{43}$ ASF, Carte strozziane, Series I, 361, fol $71 \mathrm{r}-\mathrm{v}$.

${ }^{44}$ Lorenzo Cantini, Legislazione toscana raccolta e illustrata (1532-1775), 32 vols. (Florence, 1800-1805), 2:345: 'Bando per contro delle frombe e scaglie del dì 25 Ottobre 1554.'

${ }^{45}$ For a comprehensive look at the potenze in Florence, see David Rosenthal, Kings of the Street: Power, Community, and Ritual in Renaissance Florence (Turnhout: Brepols, 2015).
} 
Balls on Walls

for the game Lo schangie, which resembles a kind of girotondo, or ring-around the-rosie type. ${ }^{46}$ Florentine youths chanted their song: 'Andrevuolo make a good game/ And whoever wants to play need not fret..., ${ }^{47}$ The musical aspects of quotidian youth games resemble the canti carnascialeschi, songs such as those by Anton Francesco Grazzini (including the aforementioned 'Song of the Game of Pome') that were written to celebrate carnival and were sung by groups, including the potenze, during public games. In both the quotidian games of youths and the organized public games, music not only created a sonic realm announcing the special time of the game, but also shouted and defined territories within the piazza. ${ }^{48}$ The parade of musicians and sounding of trumpets were fully integrated parts of the calcio game, as Bardi notes in his rules that the trumpets come first, followed by the tambourines, and then come the rest of the calcio players. ${ }^{49}$ For games in the sixteenth century, play, ritual, and music were interwoven in the signification of the game. ${ }^{50}$

Beyond a sonic marking of space, the young men who would later join the potenze and confraternities also physically demarcated their urban territories through signs and tabernacles on street corners, just as officials marked urban space in relation to play. For example, we see still surviving the marker of the Kingdom of the Red City potenza, located in Piazza Sant'Ambrogio or the marker of the area ruled by the Duca della Mela, located on Canto della Mela (Fig. 16-17).

\footnotetext{
${ }^{46}$ Alessandro Parenti, 'Scangèo' in Lingua Nostra, v. 70, n. 1-2 (2009), 40-52. The purpose of Parenti's article is to discuss the meaning and history of the word scangèo, specifically as it was used in Benedetto Varchi's Ercolano. This word appears several times in the Laurenziana manuscript, in which it refers to a type of game.

${ }^{47}$ Biblioteca Laurenziana, Manoscritto: Ashb. 732, ca. 1500, fol. 7v: 'Andrevuolo fa buon giuocho/ Et chi ci vuol giuchare non si debba schorrubbiare...'

${ }^{48}$ For more on intermittent uses of sound in the piazza, see Thomas Cohen, 'The Early Modern Italian Shout' and Massimo Rospocher, 'The Battle for the Piazza: Creative Antagonism between Itinerant Preachers and Street Singers in Late Medieval and Early Modern Italy,' in Stefano Dall'Aglio, Brian Richardson, Massimo Rospocher ed. Voices and Texts in Early Modern Italian Society (New York: Routledge, 2017).

${ }^{49}$ Bardi, 14: 'prima escono i Trombetti con la Livrea, dopo i Tamburini, et poi cominciono à venire gl'Innanzi piu giovani presi per mano'

${ }^{50}$ For how sound controlled and organized space, see Niall Atkinson, The Noisy Renaissance. Sound, Architecture, and Florentine Urban Life (University Park, PA: Penn State University Press, 2016).
} 
Balls on Walls

David Rosenthal has suggested that this permanent marking of territory demonstrated the limited agency held by the plebian potenze during moments of interpenetration of the festive and quotidian worlds, evidenced by the head of the Bargello's admission that the potenze, comprised of artisans and shop owners, generally poor people, obliged even the wealthy living in their areas to pay them to organize festivities for their neighbourhood. ${ }^{51}$ Thus the potenze used their agency during times of festivity to build community and modify their urban environment, offering points of connection and self-fashioning in a public space.

\section{Conclusion}

The ludic -- as seen in the potential for play by youths on the street -- functioned beyond festivities and the festal, and as more than the quotidian in the practice of everyday life. ${ }^{52}$ The ability of the street game to transform the urban space into a realm with new rules, creating new connections for people, new nodes of interaction, new possibilities for identity, and new sources of authority, lingered in the collective memory of the space. ${ }^{53}$ The connections and communities of games were often transient and episodic, interwoven with other communities and other uses of space. Not easily categorized or idealized, these moments of play provide a glimpse into the difficult to ascertain aspects of life and experience in urban space for groups marginalized by scholarship, often due to a lack of evidence, such as the poor. ${ }^{54}$ Marvin Trachtenberg

\footnotetext{
${ }^{51}$ David Rosenthal, 'Owning the Corner: The 'Powers' of Florence and the Question of Agency,' I Tatti Studies in the Italian Renaissance 16: 1/2 (Fall 2013): 181-196. Florence, ASF, Parte 1478, fol. 292r (1610) f. 125: '[E]t in queste potenze non ce se non arti e ci e bottegai tutta gente povero sebenne abito in dette contrade cittadini' ${ }^{52}$ Michel de Certeau reflects on the tactics individuals use in everyday life to negotiate and perform their identity with governing structures and institutions, see Michel de Certeau, The Practice of Everyday Life (Berkeley, CA: University of California Press, 1984).

${ }^{53}$ See Maurice Halbwachs and Lewis Coser (ed). On collective memory (Chicago: University of Chicago Press, 1992).

${ }^{54}$ For more on winnowing in on performance and the quotidian experience of the street, see Fabrizio Nevola, Experiences of the Street in Early Modern Italy', Special Issue as part of double issue of I Tatti Studies in the Italian
} 
Balls on Walls

demonstrated the potency of collective memory in relation to monuments and spaces in late medieval Florence. ${ }^{55}$ Games too contributed to this collective memory; The ephemeral nature of play defies its presumed boundedness by allowing there to be a change in the social order on the street. When the kinetic energy of the game has dissipated, the potential energy for play still remains. The ever present potential for the playful is evidenced in the permanent signs in urban space: the insignias of the potenze, the marble calcio marker in Santa Croce, and the obelisks in Santa Maria Novella. The plaques forbidding ball games themselves concede the possibility of youth play in the space by being necessary. In sixteenth-century Florence, games were not merely heterotopias, rather, they carved themselves physically into the urban infrastructure, becoming part of the memory, use, and meaning of the space. The Medici program to transform calcio into a personal symbol of their rule over Florence responds to the problematic political potential of a youth ball game enacted repeatedly in the urban infrastructure, a game infamously associated with the populace's defiance of their very presence in the city during the Siege of Florence. With balls on walls, sticks and bricks, feet on the streets, and throngs in song, young men asserted their presence and agency within not only the space of the game or within a prescribed moment of festivity, but also the space of the city and in the practice of everyday life.

Renaissance, 16:1/2 (Fall 2013). For the focus on aristocratic games over games by the poor, see: Guido Guerzoni, 'Ei non distingueva i giuochi patrizi da i plebei». Note sul gioco aristocratico e cortese tra Quattro e Cinquecento,' Ludica 2 (1996), 45-60.

${ }^{55}$ Marvin Trachtenberg, Dominion of the eye: Urbanism, art, and power in Early Modern Florence (Cambridge and New York: Cambridge University Press, 1997). 


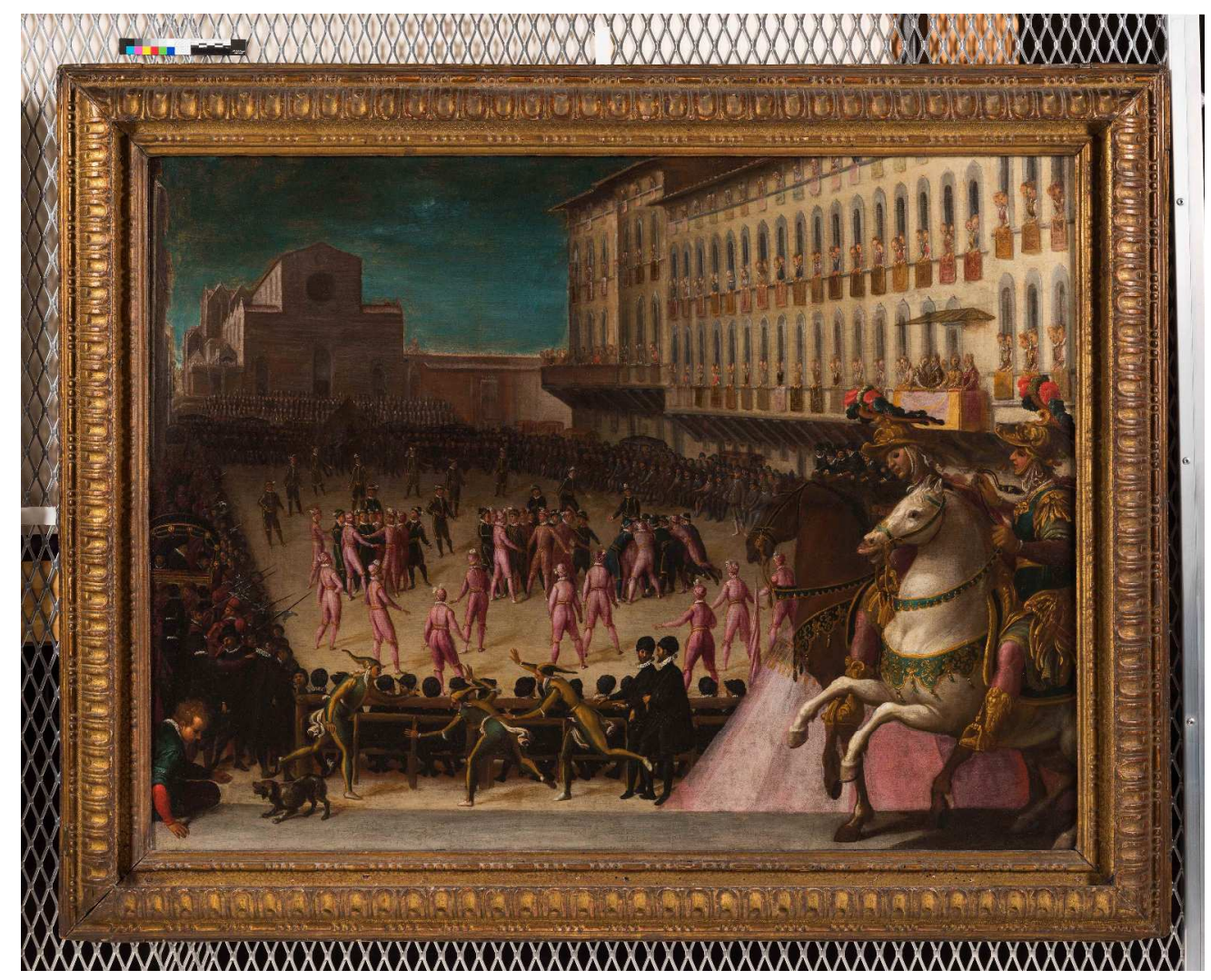

Fig. 1 Raffaello Gualterotti, Gioco del Calcio, 1589, oil on canvas, Sarasota, Florida, Ringling Museum of Art $423 \times 341 \mathrm{~mm}(300 \times 300 \mathrm{DPI})$

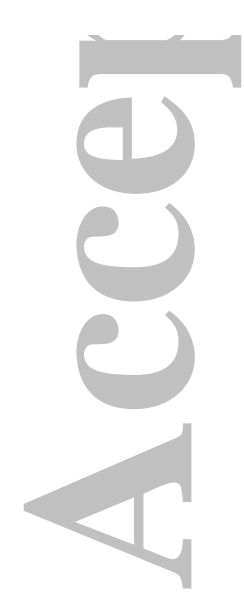




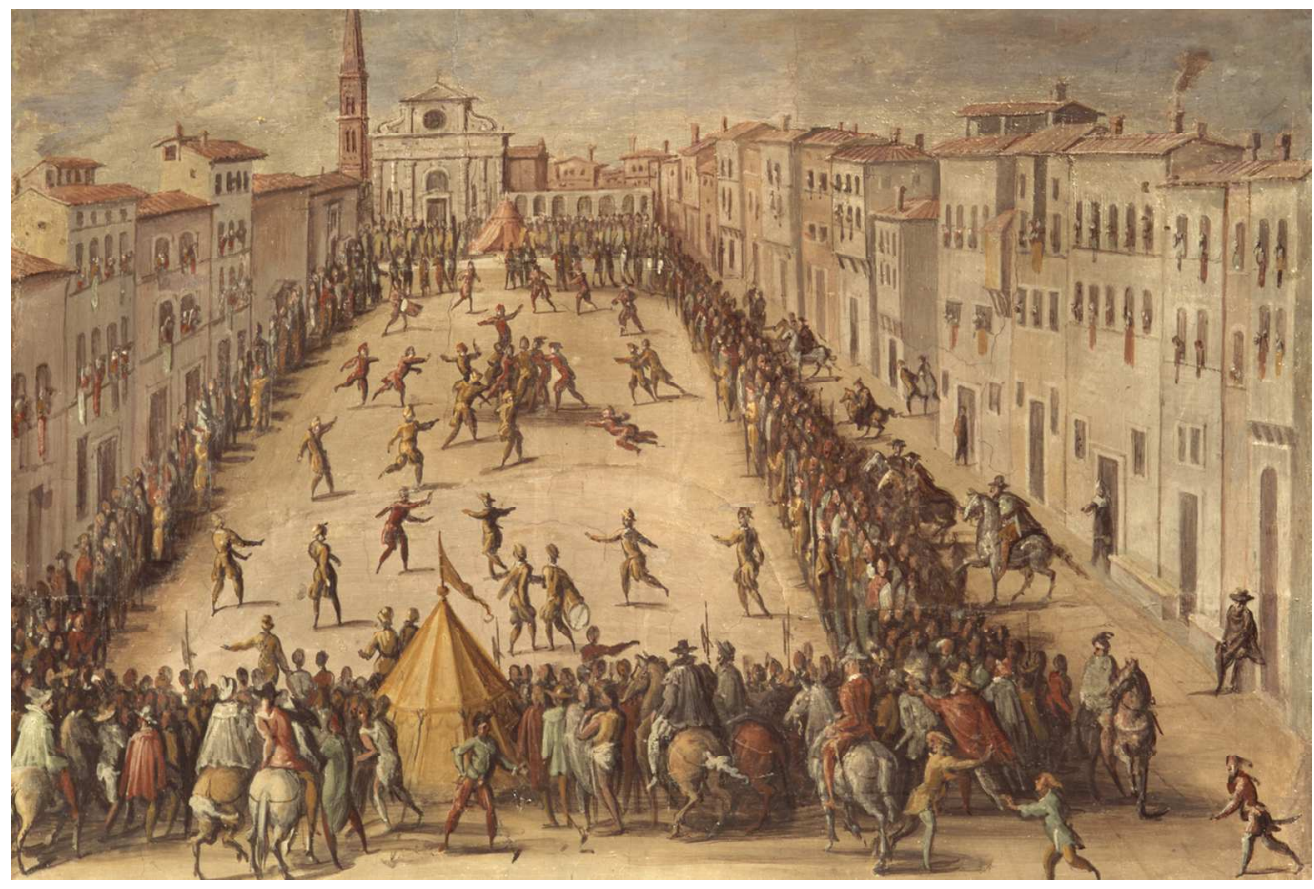

Fig. 2 Giovanni Stradano, Calcio in Santa Maria Novella in the Sala di Gualdrada, 1561-1562, fresco, Florence, Palazzo Vecchio, Art Resource

$127 \times 84 \mathrm{~mm}(300 \times 300 \mathrm{DPI})$

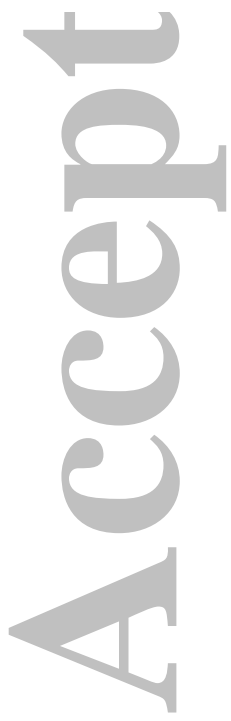




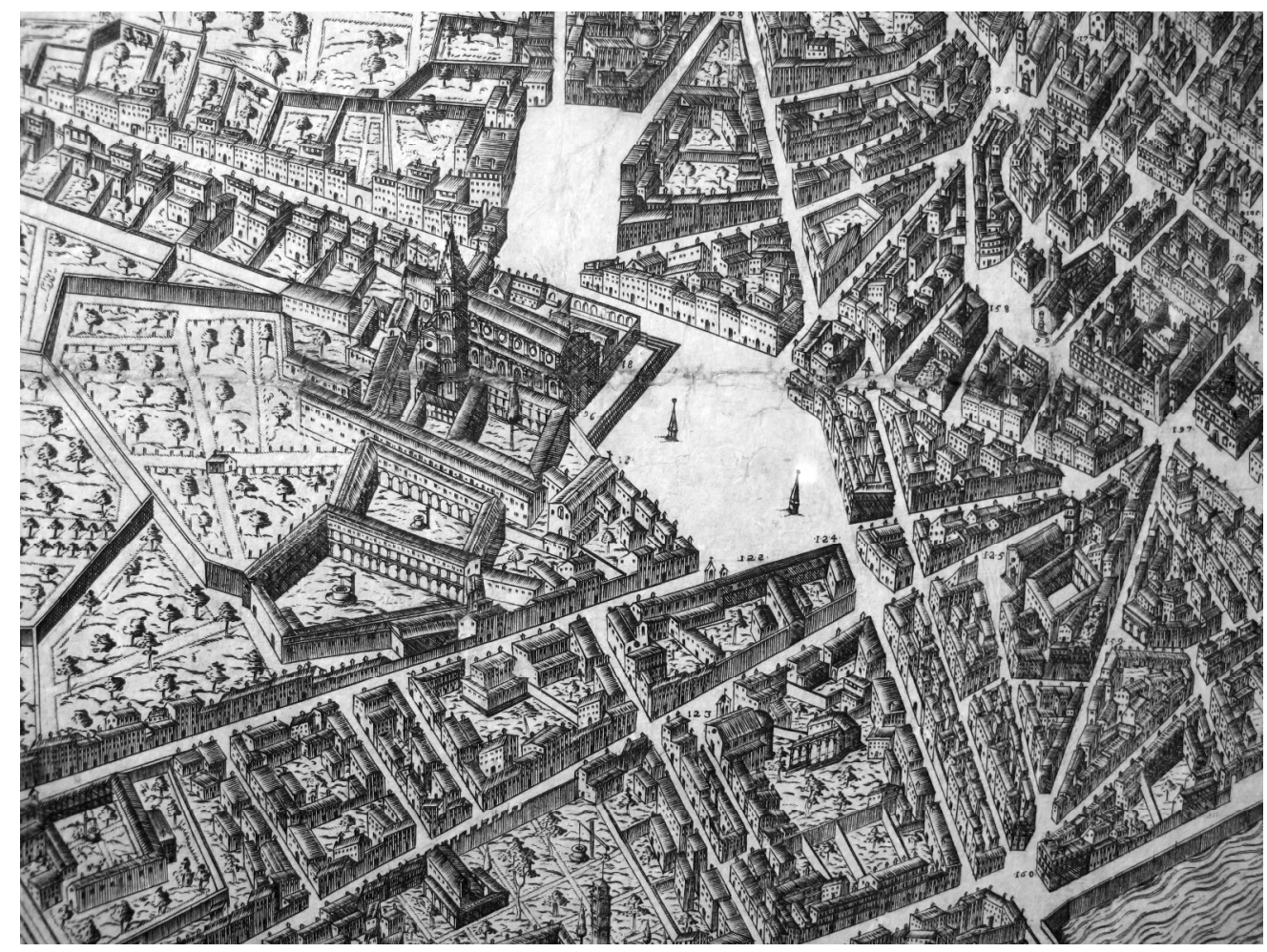

Fig. 3 Detail from Stefano Buonsignori, Nova pulcherrimae civitatis Florentiae topographia accuratissime delineata, 1584, etching, Florence; later reprinted by Gio. Iacomo de Rossi in the 17th century in Rome (Harvard College Library, accessed through the Decima Project, http://decima-map.net/)

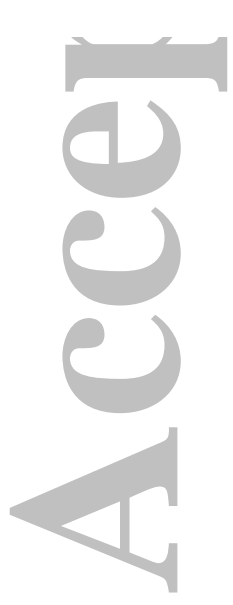

$308 \times 231 \mathrm{~mm}(300 \times 300 \mathrm{DPI})$ 


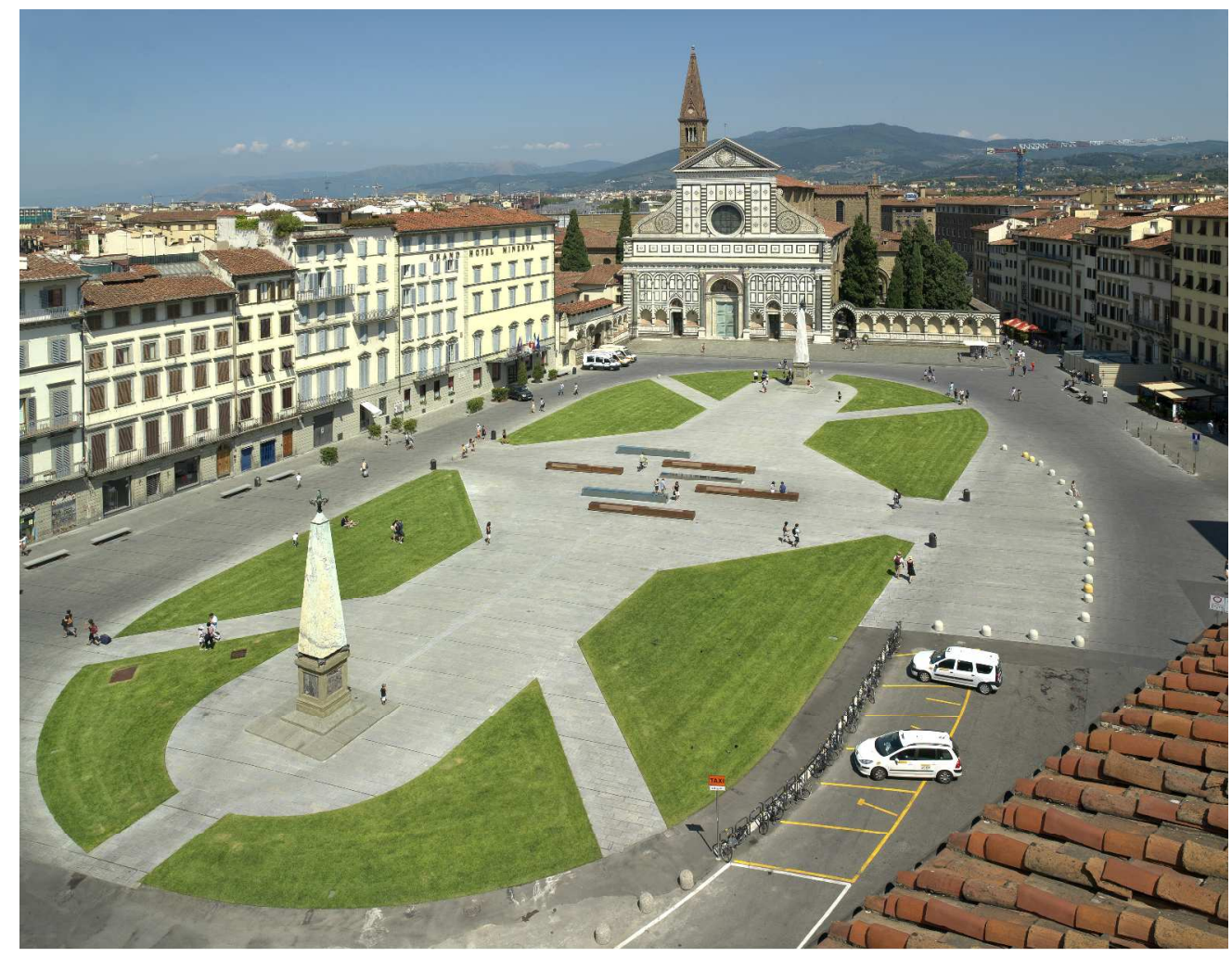

Fig. 4 Piazza Santa Maria Novella, Florence, Italy (Art Resource) $430 \times 335 \mathrm{~mm}(300 \times 300$ DPI $)$

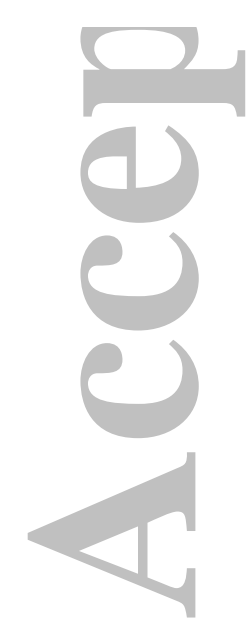

This article is protected by copyright. All rights reserved. 


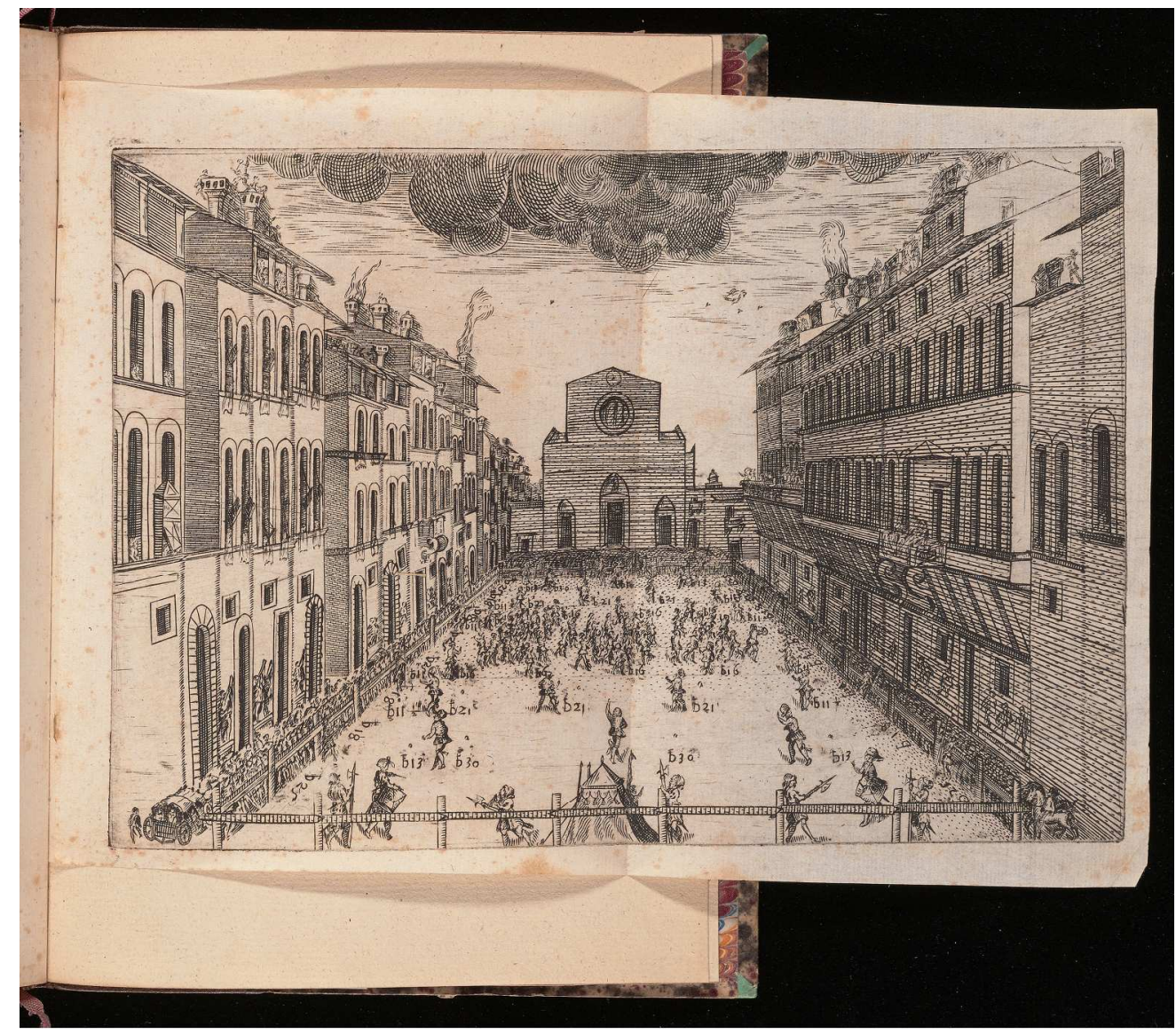

Fig. 5 Giovanni de' Bardi conte di Vernio, Discorso sopra il giuoco del calcio fiorentino del Puro Accademico Alterato, 1580, etching, Florence (Yale University, Beinecke Rare Book \& Manuscript Library)

$207 \times 183 \mathrm{~mm}(300 \times 300 \mathrm{DPI})$

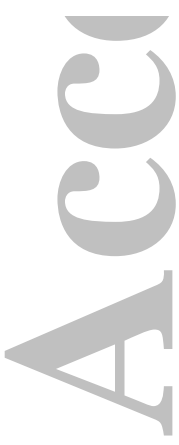




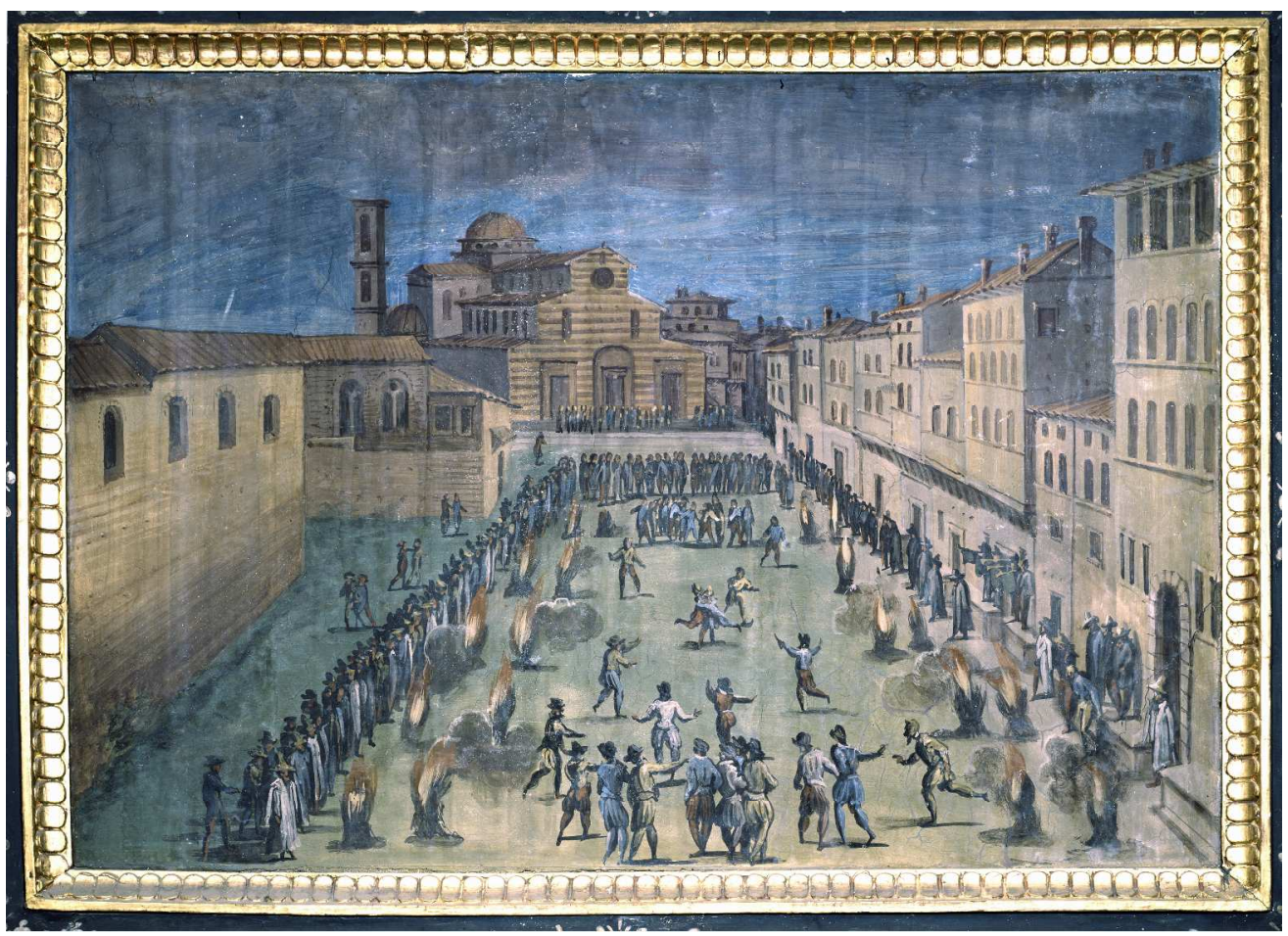

Fig. 6 Giovanni Stradano, Game of Bonfires in Piazza Santo Spirito in the Sala di Gualdrada, 1561-1562, fresco, Florence, Palazzo Vecchio (Art Resource)

$456 \times 330 \mathrm{~mm}(300 \times 300 \mathrm{DPI})$

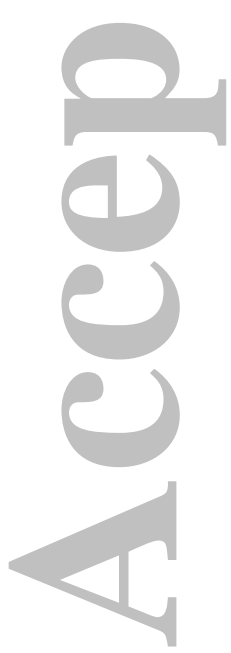




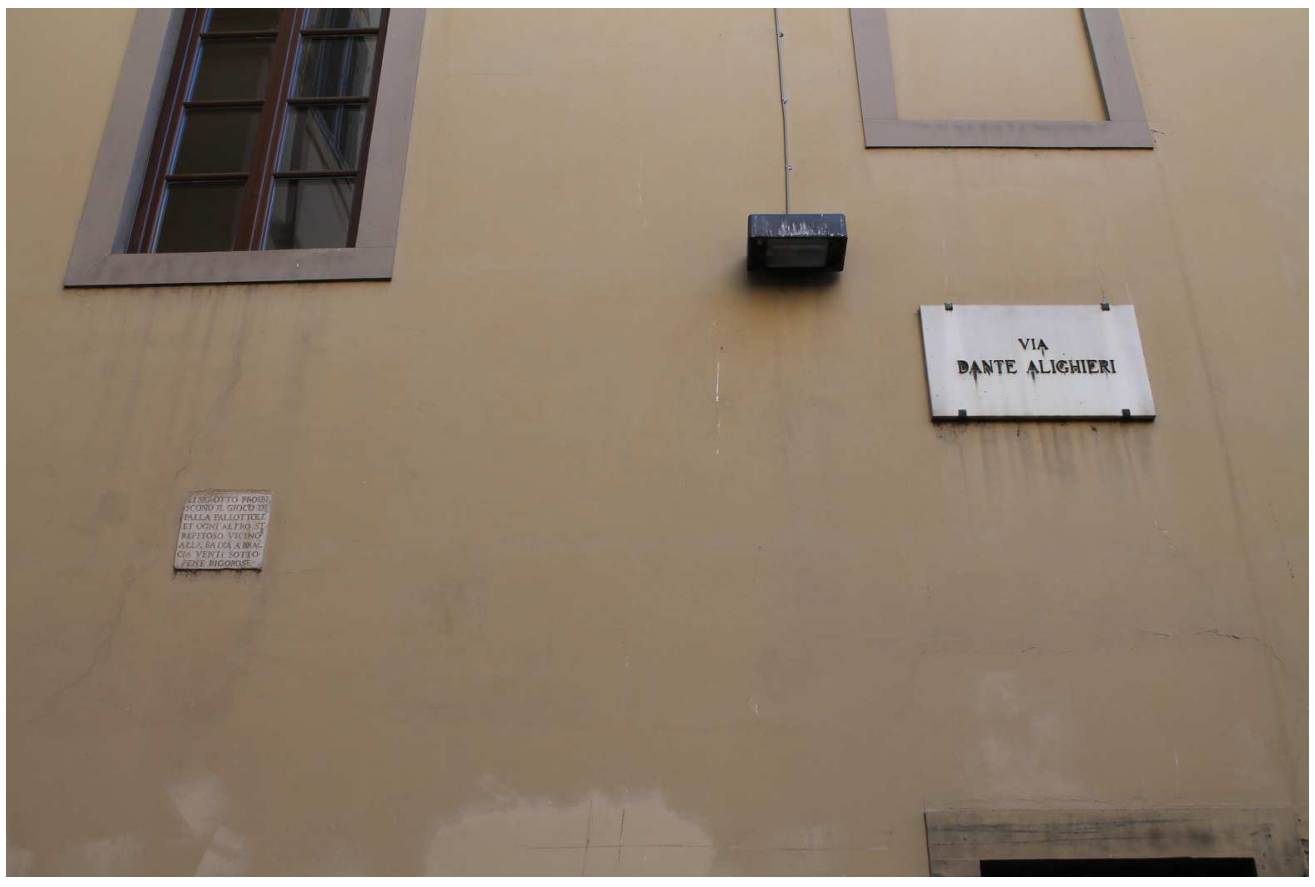

Fig. 7 Plaque prohibiting games on Via Dante Alighieri, Florence, Italy (Photo credit: author) $180 \times 120 \mathrm{~mm}(300 \times 300 \mathrm{DPI})$

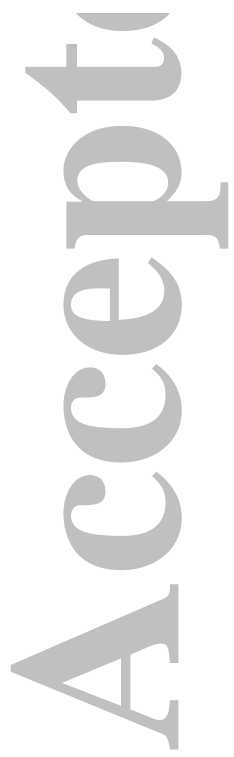




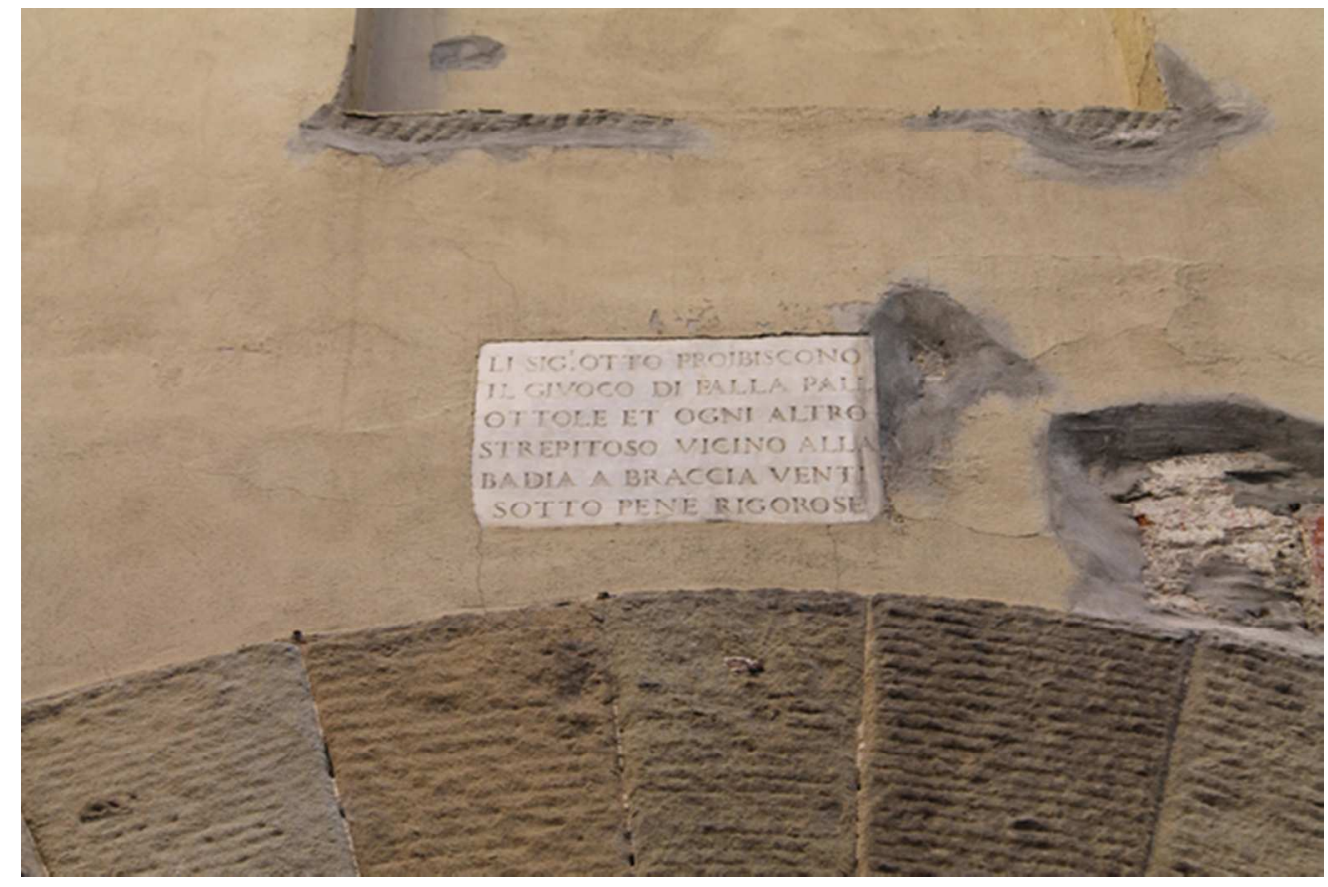

Fig. 8 Plaque prohibiting games on Via dei Magazzini, Florence, Italy (Photo credit: author) $50 \times 33 \mathrm{~mm}(300 \times 300 \mathrm{DPI})$

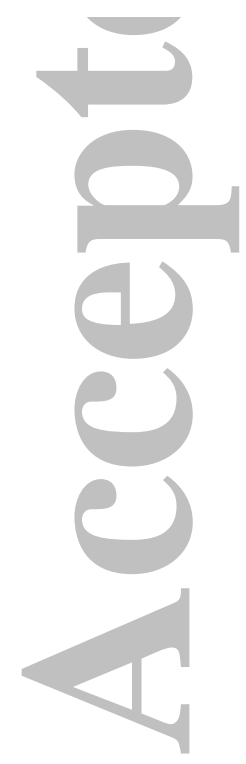

This article is protected by copyright. All rights reserved. 


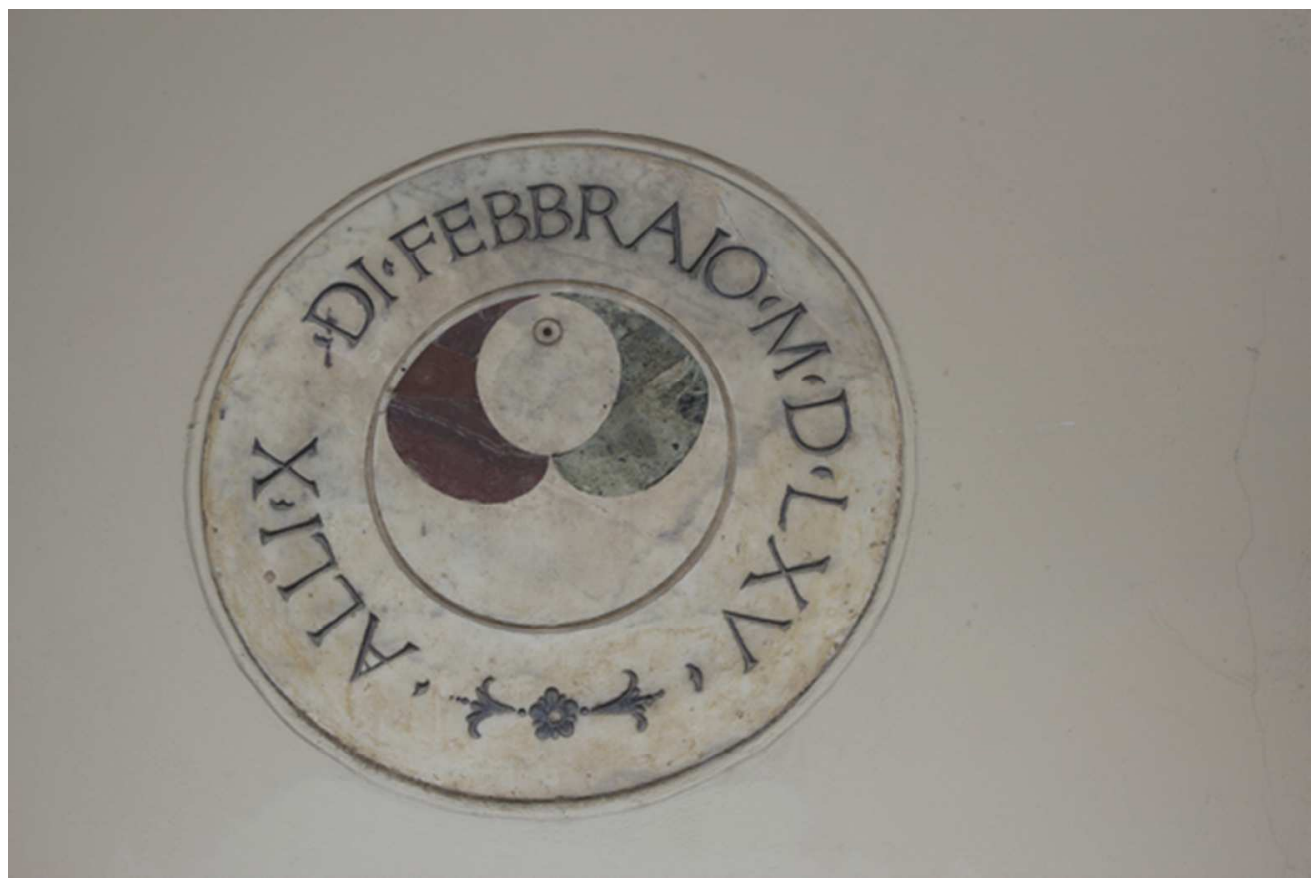

Fig. 9 Marble marker of mid-point of calcio field in Piazza Santa Croce, Florence, Italy (Photo credit: author)

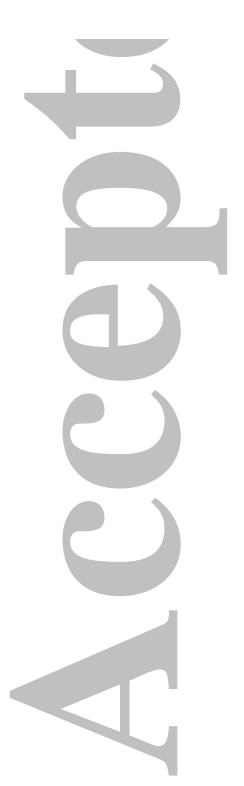
$50 \times 33 \mathrm{~mm}(300 \times 300 \mathrm{DPI})$ 


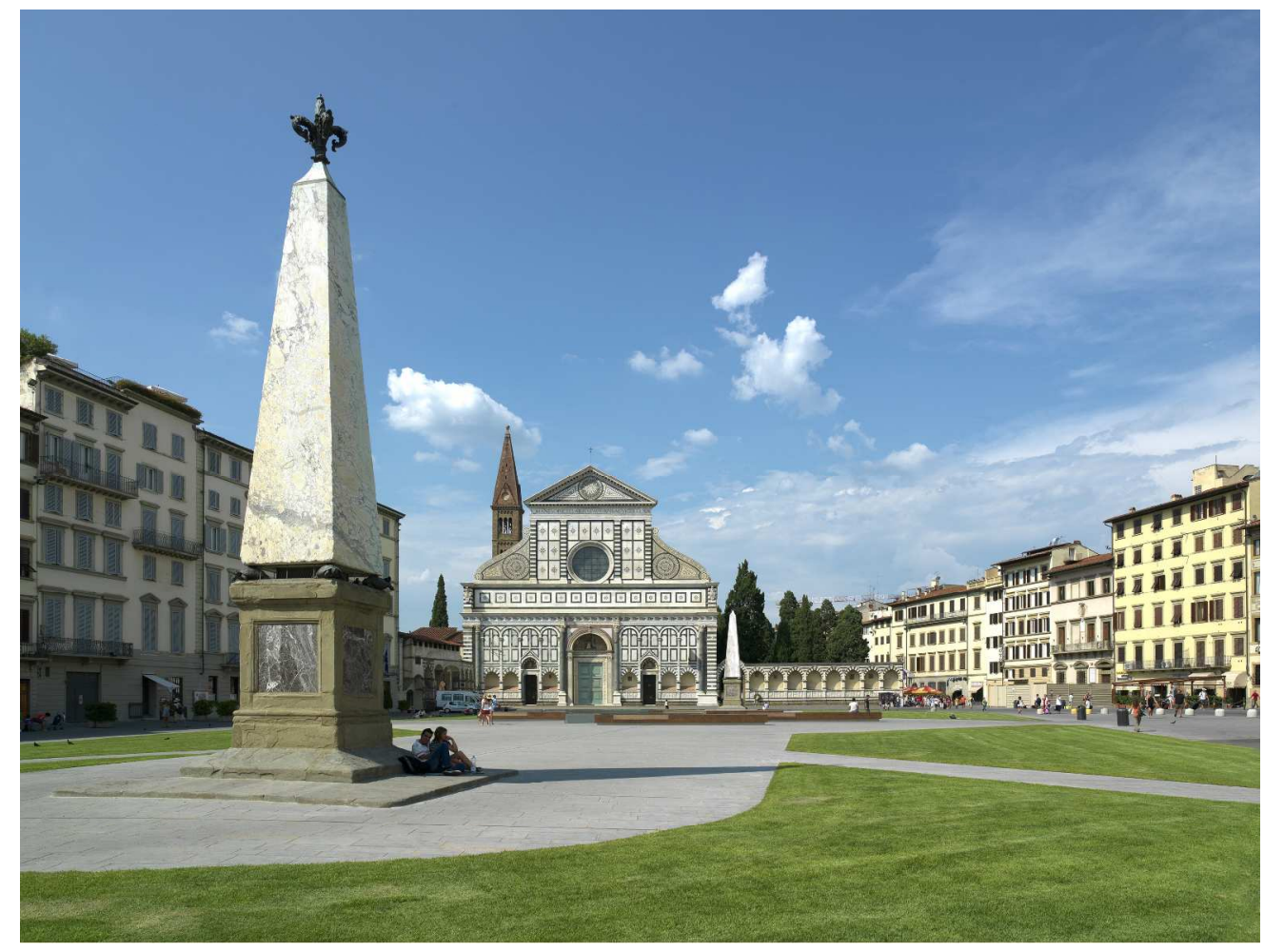

Figure 10: Bartolomeo Ammannati, Obelisks for chariot race erected in 1608, in Piazza Santa Maria Novella, Florence, Italy (Art Resource)

$256 \times 192 \mathrm{~mm}(300 \times 300 \mathrm{DPI})$ 


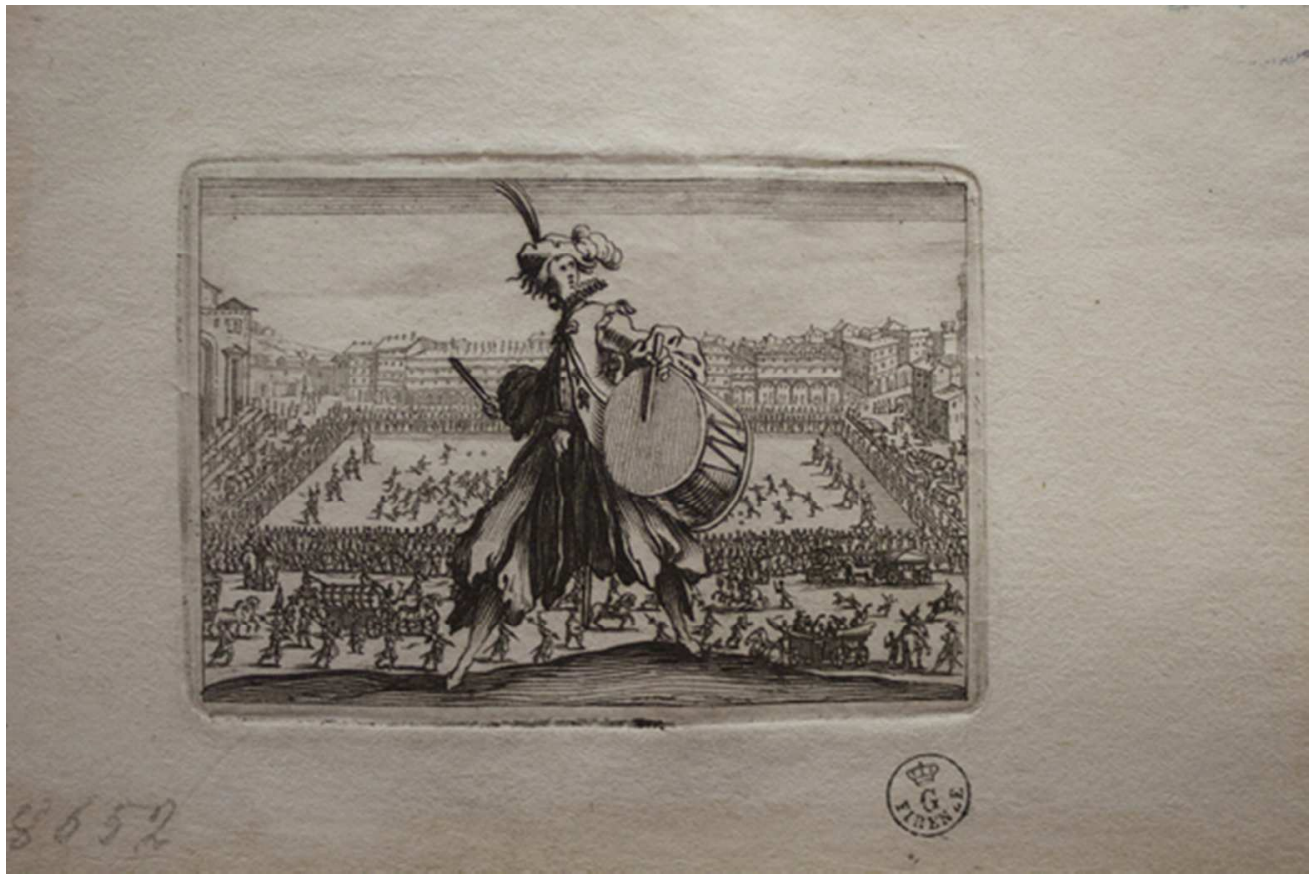

Fig. 11 Jacques Callot, View of the Calcio Storico in Piazza Santa Croce, 1617, etching, Florence, Gabinetto Disegni e Stampe degli Uffizi

$50 \times 33 \mathrm{~mm}(300 \times 300$ DPI $)$

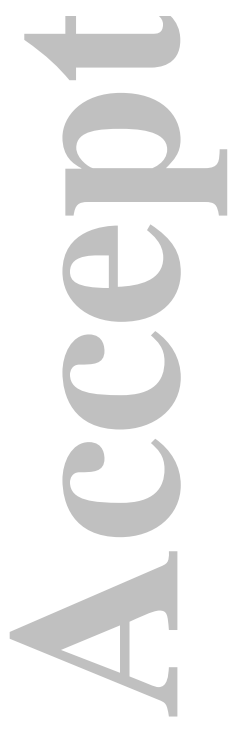




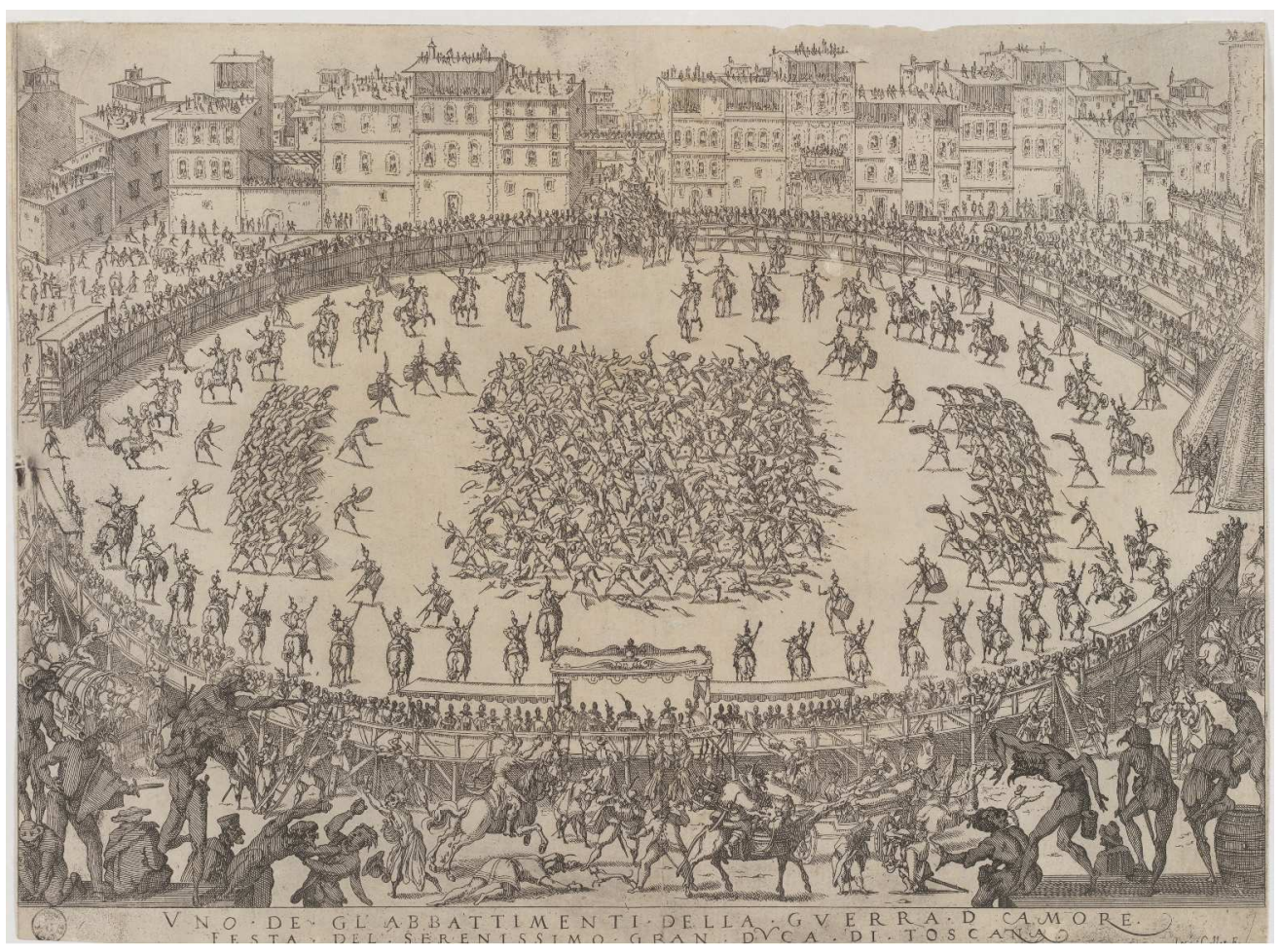

Fig. 12 Jacques Callot, Joust of Love and War in Piazza Santa Croce, 1616, etching, Florence, Gabinetto Disegni e Stampe degli Uffizi

$454 \times 334 \mathrm{~mm}(300 \times 300$ DPI $)$

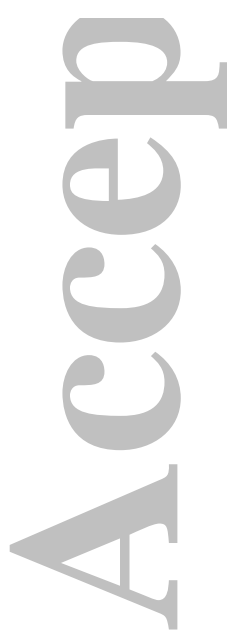




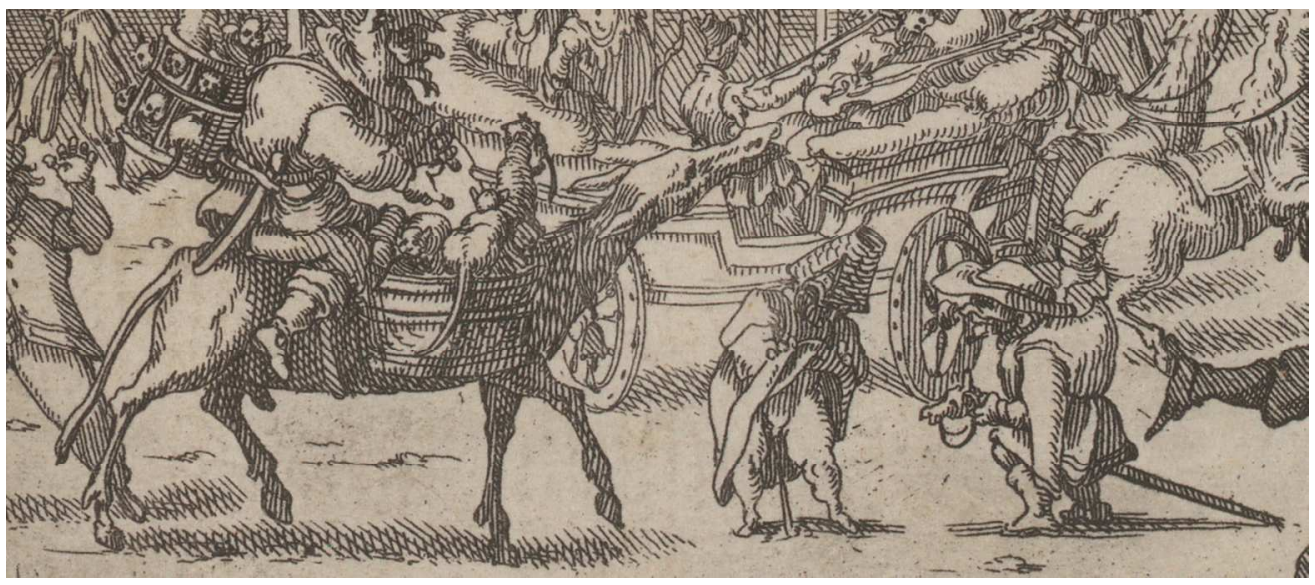

Fig. 13 Detail from Jacques Callot, Joust of Love and War in Piazza Santa Croce, 1616, etching, Florence, Gabinetto Disegni e Stampe degli Uffizi $\vdash$ T

$111 \times 48 \mathrm{~mm}(300 \times 300 \mathrm{DPI})$

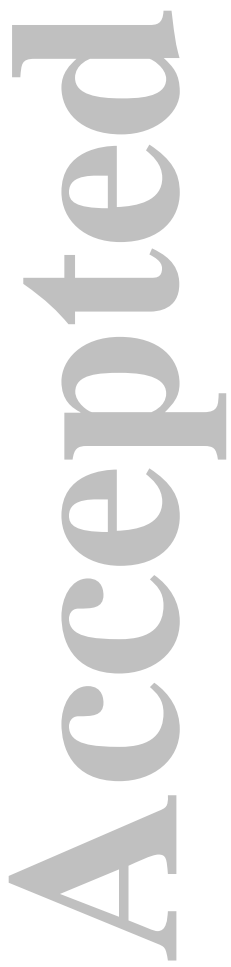




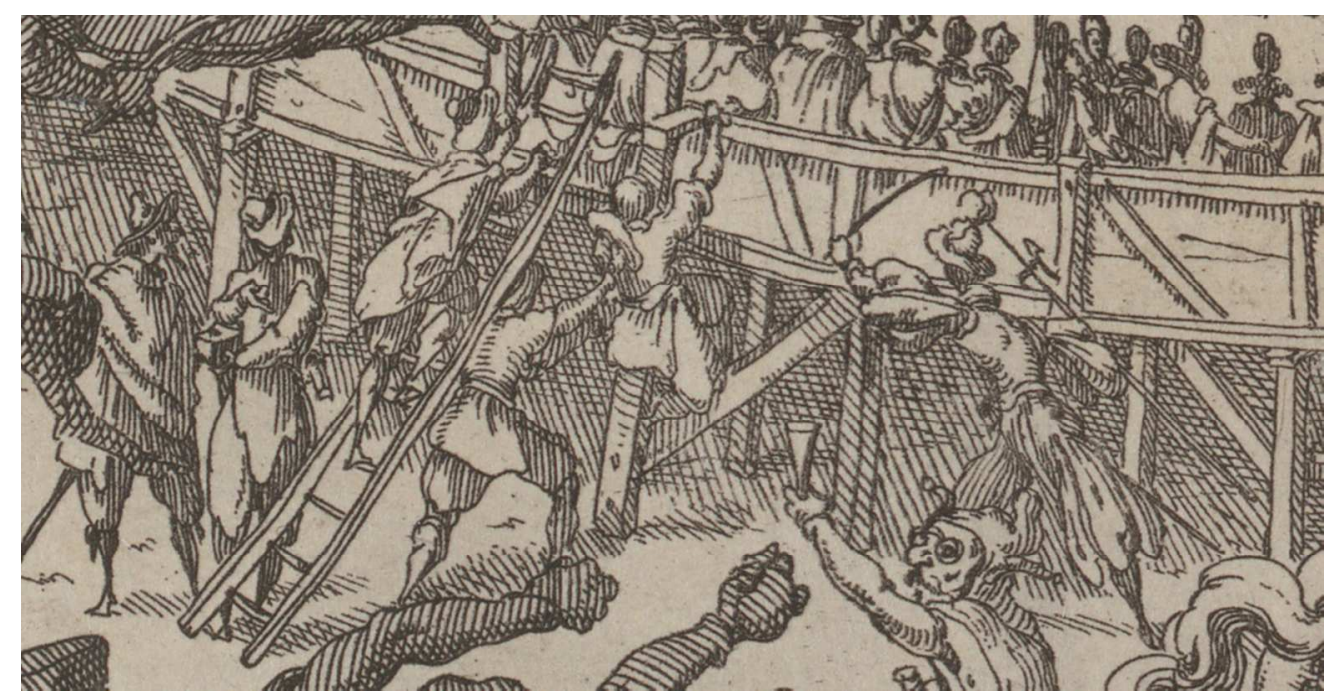

Fig. 14 Detail from Jacques Callot, Joust of Love and War in Piazza Santa Croce, 1616, etching, Florence, Gabinetto Disegni e Stampe degli Uffizi + T

$85 \times 44 \mathrm{~mm}(300 \times 300$ DPI $)$

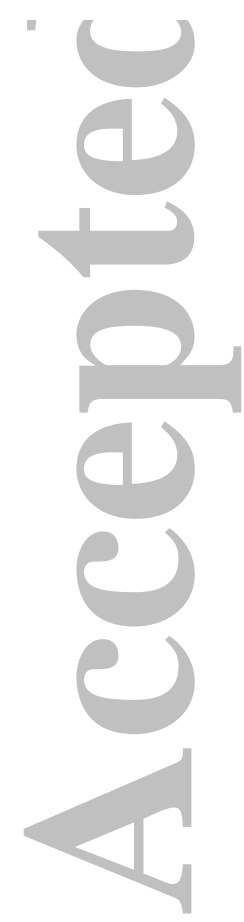




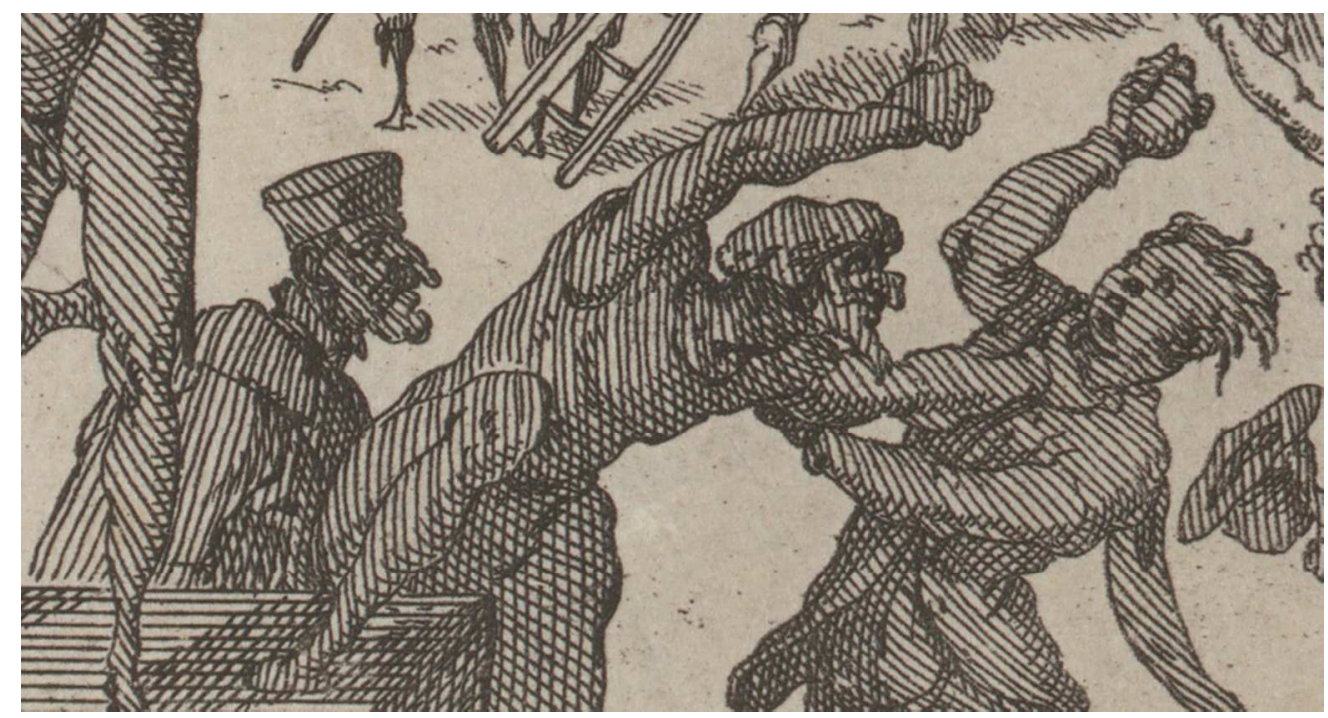

Fig. 15 Detail from Jacques Callot, Joust of Love and War in Piazza Santa Croce, 1616, etching, Florence, Gabinetto Disegni e Stampe degli Uffizi

$73 \times 39 \mathrm{~mm}(300 \times 300 \mathrm{DPI})$

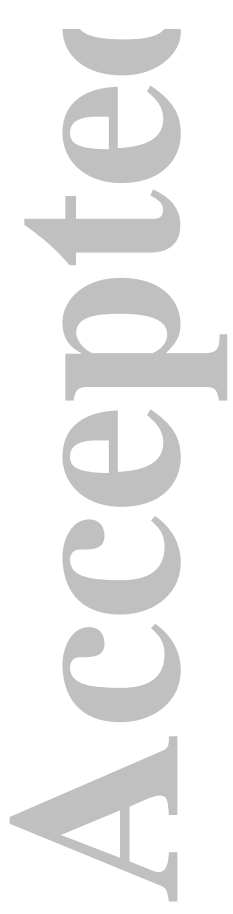




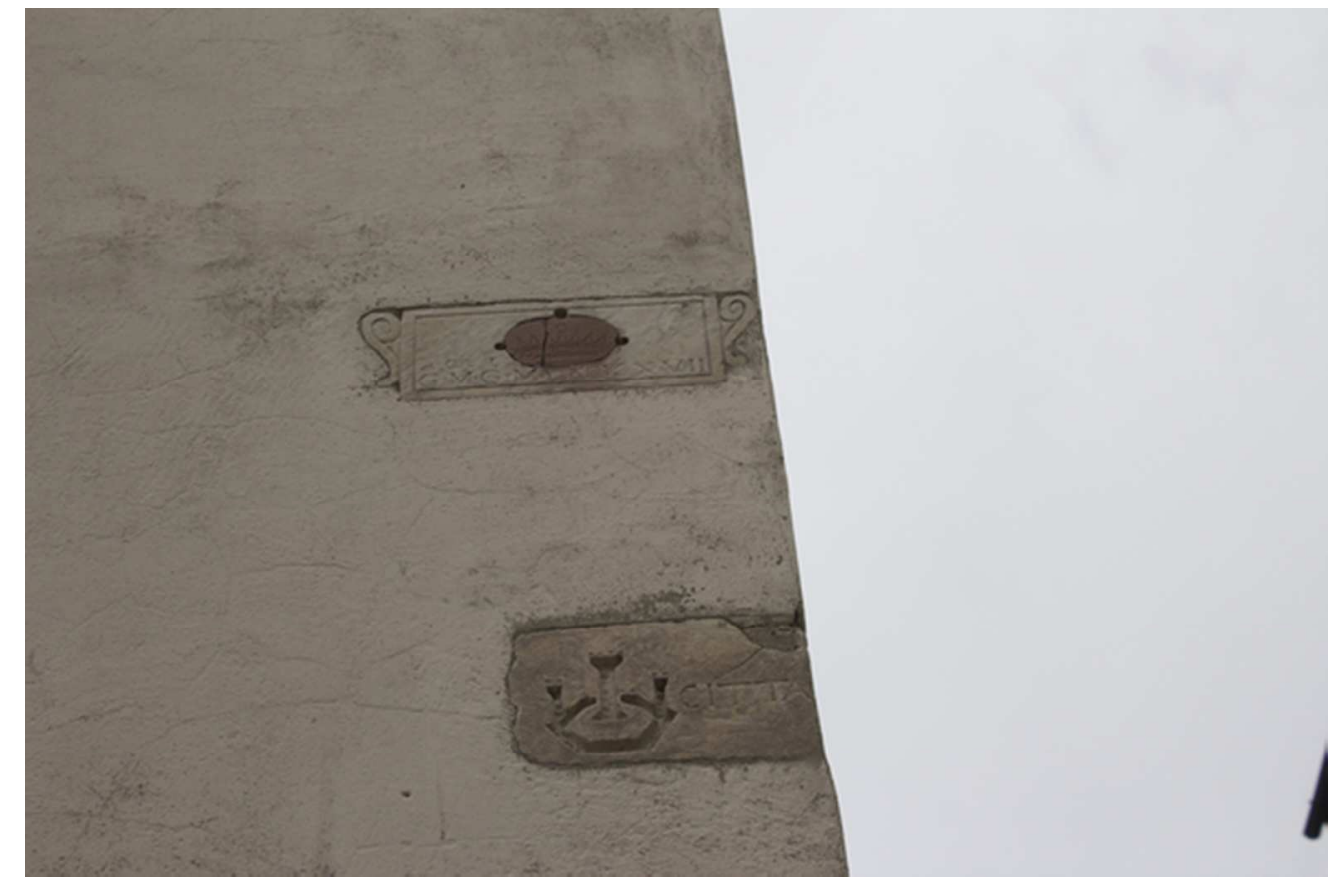

Fig. 16 Potenze marker in Piazza Sant' Ambrogio, Florence, Italy (Photo credit: author) $50 \times 33 \mathrm{~mm}(300 \times 300 \mathrm{DPI})$

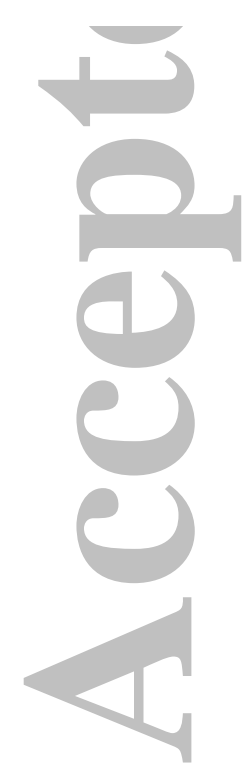




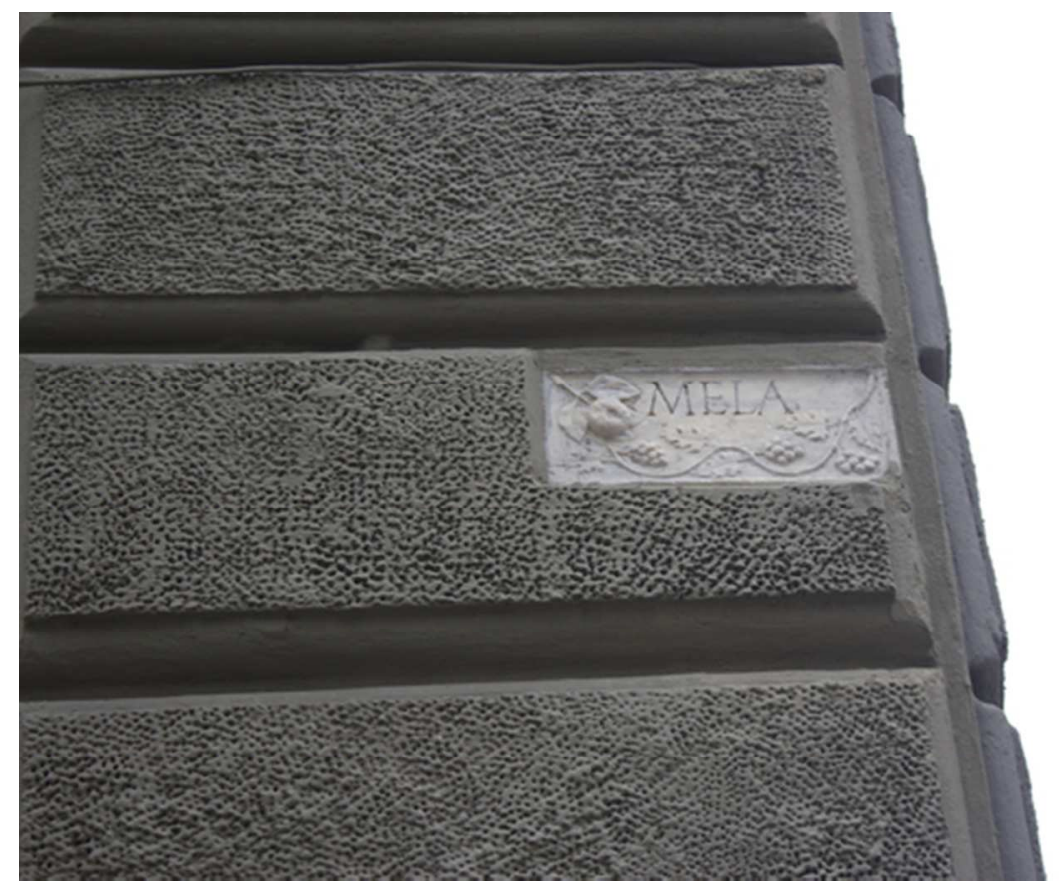

Fig. 17 Potenze marker on the Canto della Mela in Florence, Italy (Photo credit: author) $50 \times 33 \mathrm{~mm}(300 \times 300$ DPI $)$

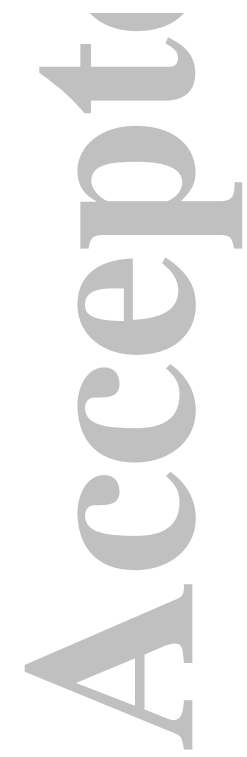

